\title{
IMPACT OF FOOD AND DRINKS ON URINE PRODUCTION: A SYSTEMATIC REVIEW
}

Upeksha S. Alwis ${ }^{1 *}$, Rebecca Haddad ${ }^{1,2}$, Thomas F. Monaghan ${ }^{3}$, Paul Abrams ${ }^{4}$, Roger Dmochowski $^{5}$, Wendy Bower ${ }^{6}$, Alan J. Wein ${ }^{7}$, Saskia Roggeman ${ }^{1}$, Jeffrey P. Weiss ${ }^{3}$, Sherif Mourad $^{8}$, Joris Delanghe ${ }^{9}$, Karel Everaert ${ }^{1}$.

${ }^{1}$ Department of Human Structure and Repair, Ghent University Hospital, Ghent, Belgium.

2Sorbonne Université, GRC 001, GREEN Groupe de recherche en Neuro-Urologie, AP-HP, Hôpital Rothschild, F-75012 Paris, France.

${ }^{3}$ Department of Urology, SUNY Downstate Health Sciences University, Brooklyn, NY. US.

${ }^{4}$ Department of Urology, Bristol Urological Institute, Bristol, United Kingdom.

${ }^{5}$ Department of Urology, Vanderbilt University Medical Center, Nashville, US.

${ }^{6}$ Department of Medicine and Community Care, University of Melbourne, Melbourne, Australia.

${ }^{7}$ Department of Urology, University of Pennsylvania Perelman School of Medicine, Philadelphia, US.

${ }^{8}$ Department of Urology, Ain Shams University, Cairo, Egypt.

${ }^{9}$ Department of Diagnostic Sciences, Ghent University Hospital, Ghent, Belgium.

Corresponding author:

Upeksha S Alwis, Department of Urology, Ghent University Hospital, Corneel Heymanslaan 10, 9000 Ghent, Belgium. Email: UpekshaSewwandi.Alwis@Ugent.be

Word count

3477 (without tables)

No of Figures

2

No of Tables

4

Author's contribution

This is the author manuscript accepted for publication and has undergone full peer review but has not been through the copyediting, typesetting, pagination and proofreading process, which may lead to differences between this version and the Version of Record. Please cite this article as doi: 10.1111/IJCP.13539

This article is protected by copyright. All rights reserved 
USA contributed in conception, design, data collection and analyzing, drafting, critical revision of the manuscript and final approval. RH contributed in data collection and analyzing, critical revision of the manuscript and final approval. TM contributed in critical revision and finalizing of the manuscript and final approval. PA, RD, WB, AJW, SR, JPW,SM and JD contributed in critical revision of the manuscript and final approval. KE contributed in conception, design, critical revision of the manuscript and final approval.

\section{Funding}

This study was sponsored by Frederik Paulson chair, Ghent University.

$\underline{\mathrm{COI}}$

Dr. Wein has served as an advisor/consultant for Avadel, GTX, Acquinox, Urovant, Medtronic, and Serenity within the last three years, outside the submitted work. Dr. Weiss is a consultant for Ferring, and the Institute for Bladder and Prostate Research, outside the submitted work. Dr. Everaert is a consultant and lecturer for Medtronic and Ferring and reports institutional grants from Allergan, Ferring, Astellas, and Medtronic, outside the submitted work. Dr. Dmochowski is a consultant for BlueWind and Viveve, outside the submitted work. Dr. Roggeman reports grants from Dr. Frederik Paulsen Chair, UGent-Ferring. Dr. Haddad reports personal fees and non-financial support from Astellas, MedDay Pharmaceuticals, Novartis Pharma SAS, Dentsply Sirona France, Pierre Fabre Medicament, Allergan France, Bayer HealthCare SAS and Vifor France SA, outside the submitted work. Other authors U. S. Alwis, T. F. Monaghan, P. Abrams, W. Bower, S. Mourad and J. Delanghe; No conflict of interest .

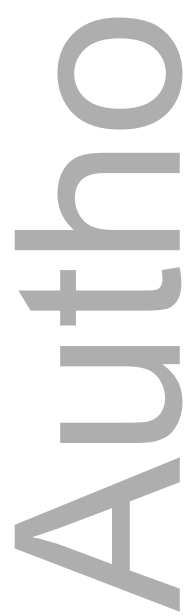

This article is protected by copyright. All rights reserved 


\section{(5) \\ Article type : Systematic Review \\ 1 \\ () \\ IMPACT OF FOOD AND DRINKS ON URINE PRODUCTION: A \\ SYSTEMATIC REVIEW}
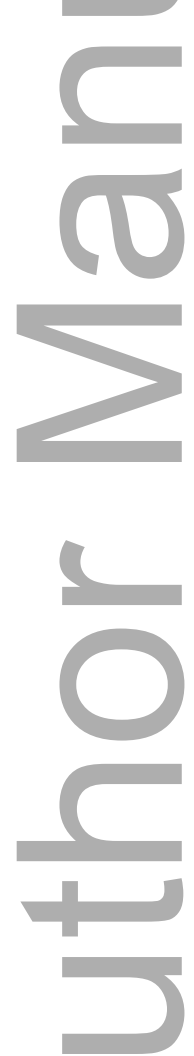

ABSTRACT

Context: The impact of food and drinks on body fluid metabolism is of direct clinical relevance but current evidence remains fragmented. Aim: Synthesize current evidence on the role of food and 
drinks in urine production. Methods: Systematic review as per PRISMA guidelines using MEDLINE and EMBASE databases (completed October 2019). Studies reporting on the effect of food, food constituents, and drinks on urine production were included. Two authors performed an independent extraction of relevant articles using predetermined datasets and completed quality-of-study indicators. Results: A total of 49 studies were included, of which 21 enrolled human subjects, and 28 were clinically- relevant animal studies (all of which utilized rodent models). The included studies were determined to be of variable quality. High dietary sodium, as well as wine, spirits, high-caffeine coffee, and caffeinated energy drinks, increased urine production in human studies. Decreased urine production was associated with low dietary sodium and consumption of milk, orange juice, and highsalt/high-sugar drinks. In animal models, a variety of fruits, vegetables, herbs, spices, and honey were associated with increased urine production. Conclusion: Current evidence suggests that although several types of food and drinks may impact body fluid metabolism, the quality of the data is variable. Urine production appears to be influenced by multiple factors including composition (i.e., moisture, macronutrients, and electrolytes), metabolite load, and the presence of specific diuresispromoting substances (e.g., caffeine, alcohol) and other bioactive phytochemicals. Future research is needed to support current evidence and the physiologic mechanisms underlying these findings.

Key words: Food, Drinks, Nutrients, Renal excretion, Urine, Fluid balance, Polyuria, Diuresis

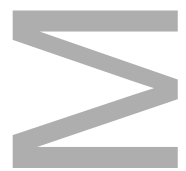

\section{Review Criteria}

- Systematic review as per PRISMA guidelines using MEDLINE and EMBASE databases.

- Comparative (randomized controlled trials [RCTs] and non-RCTs) human and animal studies reporting on the effect of food, food constituents, and drinks on urine production were included.

- Two authors performed an independent extraction of relevant articles using predetermined data sets and completed quality-of-study indicators.

\section{Message for the Clinic}

- Current evidence suggest that several types of food and drinks may impact body fluid metabolism the quality of the data is variable.

- Urine production appears to be influenced by multiple dietary factors including food composition (i.e., water, macronutrients, and electrolytes), metabolite load, and the 
presence of specific diuresis-promoting substances (e.g., caffeine and alcohol) and other bioactive phytochemicals.

\section{$\sqrt{10}$

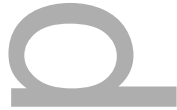 \\ (1) \\ INTRODUCTION}

Polyuria is defined by the International Continence Society as excess urine production (1). Polyuria is among the most common and bothersome urinary conditions in the general population-particularly in the context of nocturnal polyuria (i.e., excess urine production during the main sleep period) (1), which is thought to be the most common cause of nocturia overall (2).

Dietary fluid load, as a cumulative function of the volume of all drinks consumed throughout day, is strongly correlated with urine volume (3) and thus receives considerable attention in the polyuria patient interview. However potential differences in the diuretic properties of specific drinks, as well as possible complex influences from food consumption, are often overlooked. Foods, although highly variable across cultures and cuisines, may account for upwards of $20 \%$ of total daily fluid intake in the form of water in food (4). Moreover, total urine volume is a function of urinary solute excretion which, in turn, is primarily determined by the concentrating ability of the kidney in conjunction with macronutrients, minerals, and metabolites (e.g., urea) derived from food consumption (4). Alternatively, specific compounds in foods may also exert a direct diuretic effect, as widely recognized by traditional medical practices across the world, which have long employed foods and herbal remedies in the treatment of edema, hypertension, and a variety of urinary disorders (5-7).

Beyond a rudimentary assessment of total water load, the more complex role of the types of food and drinks, in the pathogenesis of polyuria, has begun to garner greater attention in current International Continence Society practice recommendations, including a multidisciplinary Delphi panel consensus statement on the importance intake diaries which incorporate foods and caloric intake (in addition to fluids) in the evaluation and management of nocturia (8). Consistently, multinational practice survey data on the treatment of nocturia in the United States and Europe suggest that initial lifestyle and behavioral counselling may include avoidance of certain foods, alcohol, and caffeine in addition to more general recommendations regarding absolute water intake (9). 
Despite these recent practice trends, more detailed evidence regarding individual foods, food constituents, and drinks in the pathogenesis of polyuria is fragmented, and specific dietary guidelines for nocturia are not available from the International Continence Society (8). Likewise, the European Food Safety Authority (EFSA), recognize that the precise physiological relationship between foods/food constituents and renal water elimination in humans remains poorly defined (10). However, preliminary evidence regarding the mechanistic relationship between individual foods, food constituents, and drinks may be extrapolated from clinically relevant animal studies, wherein a growing number of animal models have employed and refined a "diuretic index" (i.e., ratio of urine excretion in a test group to a control group) to quantitatively assess diuretic activity (11-17). Accordingly, this review aims to synthesize available evidence regarding the role of food, food constituents, and drinks on urine production in both humans and animals, which may be of direct clinical relevance in the first-line behavioral management of polyuria.

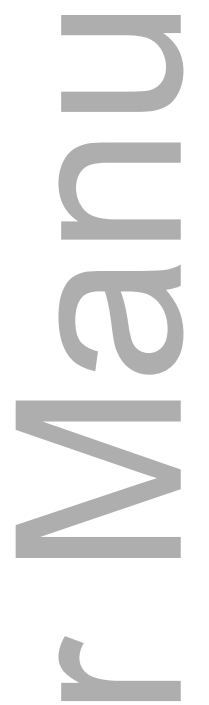

\section{METHODOLOGY}

This systematic review was conducted according to the Preferred Reporting Items for Systematic Reviews and Meta-Analyses (PRISMA) statement (18).

\section{Eligibility criteria}

Populations and Types of studies/Interventions

Comparative (randomized controlled trials [RCTs] and non-RCTs) human and animal studies investigating the diuretic effect of specific orally-ingested foods, food extracts/herbal teas, and drinks were included. Studies performed on medicinal plants without any food use or single phytochemicals isolated from plants were not included. Plant materials which are not typically known as food, were checked for their food use referring to www.wikipedia.org (Supplementary data 1). 


\section{Outcomes}

The primary outcome was the effect of food, food extracts/nutrients, and drinks on urine volume (UV). Specific effects of these substances on urinary sodium $\left(\mathrm{UNa}^{+}\right)$, potassium $\left(\mathrm{UK}^{+}\right)$, and chloride $\left(\mathrm{UCl}^{-}\right)$excretions were also recorded when available.

\section{Search strategy}

The MEDLINE and EMBASE databases were searched with no restriction on publication date. The search was completed in October 2019. Only English-language studies were included. The complete search strategy is outlined in Supplementary Data 1.

\section{Data collection and analysis}

Two review authors (U.S.A., R.H.) independently screened the abstracts of all publications rendered by the predefined search criteria. The full text of potentially eligible research items was evaluated and abstracted using a standardized spreadsheet to capture information on study design, specific exposures, and outcomes. The risk of bias was assessed using RoB 2.0 (Risk-of-Bias tool for cross-over trials) (19) and SYRCLE's RoB (SYRCLE's risk of bias tool for animal studies) (20) tools.

\section{RESULTS}

The study selection process is outlined in Figure 1. A total of 49 studies met the criteria for inclusion. Twenty-one human studies evaluated the effect of dietary sodium, sports drinks, meat, sugars/sweeteners, milk/milk-based drinks, tea, coffee, alcohol, and energy drinks on urine volume (UV). Twenty-eight animal studies assessed the effect of honey, fruits, vegetables, herbs, and spices on UV. All 28 animal studies employed rodent models. All results are reported using mean values unless otherwise specified (Tables 1, 2, 3, 4). The risk of bias of selected studies was highly variable (Supplementary 2).

\section{HUMAN STUDIES}

\section{A. Electrolytes}

a. Dietary Sodium

In 4 human studies, participants were administered a sodium-controlled diet for a period of 1 to 3 weeks (21-24). Three studies enrolled healthy subjects and reported no difference in UV between a high vs. normal or low-salt diet (21-23). One study enrolled patients with hypertension and reported a significant increase in UV in the high-salt diet (UV: $2046.3 \mathrm{~mL} / 24-\mathrm{h}$ ) compared to the low-salt diet 
(1751.6 $\mathrm{mL} / 24-\mathrm{h})$ in subjects with the highest $\mathrm{UNa}^{+}$excretion tercile (24). $\mathrm{UNa}^{+}$excretion was significantly different between groups in all 4 studies.

Four others studies reported the effect of salt intake on UV (25-28). In healthy women, a $24 \%$ increase in UV (30 vs $37.8 \mathrm{ml} / \mathrm{kg} / 24-\mathrm{h}$ ) and a six-fold increase in $\mathrm{UNa}^{+}$excretion from low-to-high dietary sodium were observed (26). Similar results were reported in healthy young adults (28), healthy males (25) and untreated hypertensive patients (27).

\section{b. Salted water}

One RCT reported a significant reduction in UV with $27 \mathrm{mmol} / \mathrm{L}$ and $52 \mathrm{mmol} / \mathrm{L}$ sodium drinks compared to $7 \mathrm{mmol} / \mathrm{L}$ and $15 \mathrm{mmol} / \mathrm{L}$ solutions in healthy men (29). $\mathrm{UNa}^{+}$excretion was not reported.

c. Sports drinks

Sports drinks are characterized by a high electrolyte content (30). Two RCTs of healthy men found no significant difference in UV with sports drinks compared to water $(30,31)$.

\section{B. Osmotically active substances}

a. Sugars

In a RCT comparing orange juice and cola to still water in men (30), UV was significantly lower following consumption of orange juice vs. still water but not significantly changed with cola.

Another RCT reported a significant decrease in UV in men with $10 \%$ - and $20 \%$-sucrose drinks compared to water, whereas no effect was observe with $5 \%$ sucrose drink (29). UNa ${ }^{+}$excretion was not reported.

b. Sugar substitutes/sweeteners

Diet cola (30) and saccharin-sweetened water (32) intake showed similar UV $(30,32), \mathrm{UNa}^{+}(30)$, and $\mathrm{UK}^{+}(30)$ excretion patterns to still water in humans.

c. Alcohol

Consumption of wine and spirits by older men led to a significant increase of UV and decrease of $\mathrm{UNa}^{+}$and $\mathrm{UK}^{+}$excretion compared to their non-alcoholic drinks (33). Beer showed no difference in UV $(30,33)$ compared to non-alcoholic beer $(33)$ or to water $(30)$. Total UV upon ingestion of alcoholic beer and non-alcoholic beer was significantly higher than for all other alcoholic and their nonalcoholic drinks (33). Sequential consumption of beer followed by water compared to water alone had no significant effect on UV, $\mathrm{UNa}^{+}$, or $\mathrm{UK}^{+}(34)$.

This article is protected by copyright. All rights reserved 
d. Meat

A non-RCT enrolled healthy males who consumed an average $3.5 \mathrm{~g} / \mathrm{kg}$ body weight of lean cooked beef steak on the test day and an amount of sodium and water equivalent to the steak on the control day (35). Compared to the control, $\mathrm{UNa}^{+}$and $\mathrm{UK}^{+}$excretion increased significantly during the 3 hours following the protein load. Urinary flow rate $(4.6 \mathrm{ml} / \mathrm{min})$ didn't increase compared to the control $(6.1 \mathrm{ml} / \mathrm{min})(35)$.

\section{Milk and milk-based drinks}

Two RCTs reported a decrease in UV in men who ingested milk versus water. In the first study, UV was significantly reduced with full-fat (1052 g/4h) and skim (1049 g/4h) milk compared to still water (1337 g/4h) (30). In the second study, significantly decreased UV was noted after ingesting skim milk $(794 \mathrm{~mL} / 5 \mathrm{~h})$ versus water $(1429 \mathrm{~mL} / 5 \mathrm{~h})(31)$.

The consumption of yoghurt drinks by men did not significantly affect UV but did significantly increase $\mathrm{UNa}^{+}, \mathrm{UK}^{+}$and $\mathrm{UCl}^{-}$excretion (36).

\section{Caffeinated drinks}

a. Coffee

A RCT demonstrated an increase in $\mathrm{UNa}^{+}$excretion among men who consumed caffeinated coffee compared to decaffeinated coffee, but had no impact on UV (37). However, ingestion of caffeinated coffee significantly increased UV (215 ml/h to $362 \mathrm{ml} / \mathrm{h}$ ) and $\mathrm{UNa}^{+}$and $\mathrm{UK}^{+}$compared to baseline values (37). Two other crossover studies involving men reported similar results $(30,38)$.

In two crossover studies $(39,40)$, significantly greater $\mathrm{UV}, \mathrm{UNa}^{+}$and $\mathrm{UK}^{+}$were reported in adults with high-caffeine coffee compared to water and low-caffeine coffee. No significant effects on UV, $\mathrm{UNa}^{+}$ or $\mathrm{UK}^{+}$were observed with low-caffeine coffee compared to water (39). The second study reported significantly increased UV following caffeinated coffee intake compared to baseline values (40).

b. Tea

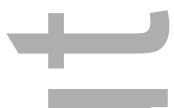

No significant difference in UV was observed between men drinking tea compared to water (30).

c. Energy drinks

Energy drinks generally contain high amount of caffeine (41). Significantly greater UV and UNa ${ }^{+}$were observed with consumption of energy drinks compared to placebo (UV: $+243 \mathrm{ml} / 6-\mathrm{h}, 95 \% \mathrm{Cl}$ [115372]) (41).

d. Caffeinated water

This article is protected by copyright. All rights reserved 
A RCT comparing ingestion of caffeinated water volume at various concentrations (up to $400 \mathrm{mg} / \mathrm{L}$ ) (29) reported no significant difference in UV, compared to non-caffeinated water.

\section{ANIMAL STUDIES}

\section{A. Sports drinks}

A single animal study identified no significant effect on $\mathrm{UV}, \mathrm{UNa}^{+}$or $\mathrm{UK}^{+}$when rats ingested sports drinks compared to water (42).

\section{B. Milk and milk-based drinks}

In rodent models, oral administration of full-fat milk decreased $\mathrm{UV}$ and increased $\mathrm{UNa}^{+}$and $\mathrm{UK}^{+}$ excretion (42), whereas a milk protein solution reduced UV with no change in $\mathrm{UNa}^{+}$and $\mathrm{UK}^{+}$excretion (42), and a milk electrolyte solution increased $\mathrm{UNa}^{+}$and $\mathrm{UK}^{+}$excretion with no significant change in UV (42).

\section{Fruits}

a. Prickly pear

Infusions of cladode, flower, and fruit significantly increased total 24-hour UV (38.2, 32.4 and 39.0 $\mathrm{mL}$, respectively) compared to the controls $(24.2 \mathrm{~mL})(43)$. No significant effect was observed on $\mathrm{UNa}^{+}$and $\mathrm{UK}^{+}$excretion.

b. Grangel

Aqueous fruit extract at 20, 40 and $60 \mathrm{mg} / \mathrm{kg}$ significantly increased 24-hour UV (9.86, 12.02, and $13.48 \mathrm{~mL} / 24-\mathrm{h}$, respectively) compared to the control (4.97 mL/24 hours) (44).

\section{c. Wild raspberry}

Methanol extract significantly increased UV $(2.32 \mathrm{~mL} / 100 \mathrm{~g})$ compared to controls $(1.3 \mathrm{~mL} / 100 \mathrm{~g})$ (12). In addition, wild raspberry extract significantly reduced the $\mathrm{UK}^{+}$excretion and increased $\mathrm{UNa}^{+}$ excretion. $\mathrm{UV}, \mathrm{UNa}^{+}, \mathrm{UK}^{+}$excretion with raspberry aqueous extract were similar to controls (12).

d. Goji berries

Oral administration of 250 and $500 \mathrm{mg} / \mathrm{kg}$ goji berry powder, significantly increased UV (8.08 and $10.05 \mathrm{ml} / 100 \mathrm{gm} / 24$ h respectively) in a dose-dependent manner (13). $\mathrm{UNa}^{+}$and $\mathrm{UCl}^{-}$excretion were significantly increased compared to controls. A significant decrease in $\mathrm{UK}^{+}$excretion was observed compared to controls.

e. Bijaura fruit 
Oral administration of fruit juice significantly increased UV $(22.17 \mathrm{~mL})$ compared to controls (16.83 $\mathrm{mL})(45)$.

D. Vegetables

a. Roselle

Aqueous extracts dosed at 1500, 2000, and $2500 \mathrm{mg} / \mathrm{kg}$ significantly increased UV (3.0, 4.3, and 4.4 $\mathrm{ml} / \mathrm{h}$, respectively) compared to baseline $(1.0 \mathrm{ml} / \mathrm{h})$. UNa ${ }^{+}$also significantly increased in a dosedependent manner whereas $\mathrm{UK}^{+}$excretion was unchanged (46).

b. Amaranth

Amaranth aqueous extracts showed no significant effect on UV (14). Conversely, $\mathrm{UNa}^{+}, \mathrm{UK}^{+}$, and $\mathrm{UCl}^{-}$ excretion were significantly increased with $500 \mathrm{mg} / \mathrm{kg}$ dosing as compared to controls.

c. Nasturtium

Compared to controls, UV and $\mathrm{UNa}^{+}$excretion significantly increased with ethanolic extract. No significant effect was observed in $\mathrm{UK}^{+}$excretion (47).

d. Moringa

Moringa leaf aqueous and hot tea extracts significantly increased $\mathrm{UV}, \mathrm{UNa}^{+}, \mathrm{UK}^{+}$, and $\mathrm{UCl}^{-}$excretion compared to the control group (15).

e. Wild mushroom

All doses of wild mushroom extract significantly increased UV at 6- and 24-hour intervals as compared to the control group (48). Twenty-four-hour $\mathrm{UNa}^{+}, \mathrm{UK}^{+}$, and $\mathrm{UCl}^{-}$excretion were also significantly higher at all-time points compared to the control group. Long-term doses of 250 and 500 $\mathrm{mg} / \mathrm{kg}$ significantly increased 24-hour UV (24.75 and $28.67 \mathrm{ml}$, respectively) compared to controls (22.5 ml). UNa+, $\mathrm{UK}^{+}$, and $\mathrm{UCl}^{-}$were also significantly increased by all doses (48).

f. Black radish

Ingestion of aqueous extracts significantly increased $24-\mathrm{h}$ UV (6.24 to $9.93 \mathrm{~mL})$ in a dose-dependent manner (49).

g. Sorrel

Ethanol extracts dosed at 750 and $1000 \mathrm{mg} / \mathrm{kg}$ significantly increased UV (3.5 and $4.2 \mathrm{~mL}$, respectively) compared to controls (16). Significant increases in the excretion of $\mathrm{UNa}^{+}, \mathrm{UK}^{+}$and $\mathrm{UCl}^{-}$ was observed with ethanol extracts in a dose-dependent manner.

This article is protected by copyright. All rights reserved 
h. Kidney leaf morning glory

Aqueous extract dosed at $600 \mathrm{mg} / \mathrm{kg}$ significantly increased UV $(2.61 \mathrm{~mL} / 5$ hours $)$ and $\mathrm{UNa}^{+}$and $\mathrm{UK}^{+}$ excretion compared to controls (UV: $1.55 \mathrm{~mL} / 5$ hours) (50).

\section{E. Herbs and spices}

a. Cardamom

Crude extract at doses of 1,3 and $10 \mathrm{mg} / \mathrm{kg}$ significantly increased UV $(4.1,5.0,5.5 \mathrm{ml} / 100 \mathrm{~g} / 6 \mathrm{~h}$ respectively) compared to the control group $(3.4 \mathrm{ml})$. $\mathrm{UNa}^{+}$and $\mathrm{UK}^{+}$excretion were also significantly increased at these doses compared to the control group (51).

b. Parsley

Two studies have reported increased UV after ingestion of parsley extract. In the first study, 24-hour UV was significantly increased compared to placebo (12.8 vs $10.9 \mathrm{ml})$ (52). Similar results were reported in the second study (53).

c. Rosemary

Aqueous extract (8\%) significantly increased 24-hour UV from study day 5 onwards. $\mathrm{UNa}^{+}$excretion was increased on the first study day and then again from the fifth study day onwards compared to controls (54). UK ${ }^{+}$excretion was significantly increased across the study period except for a single day. Sixteen percent aqueous extract significantly reduced $U V, \mathrm{UNa}^{+}$, and $\mathrm{UK}^{+}$on study day 1 , while significant increases in $\mathrm{UNa}^{+}$and $\mathrm{UK}^{+}$were noted at later time points (54).

d. Aniseed oil

A significant anti-diuretic effect was observed with aniseed oil mixed with drinking water compared to controls (urine-to-water intake ratio 27.7 versus 47.36 ), with no significant effect on water intake compared to controls ( 35.94 versus $33.78 \mathrm{ml}$ ) (55).

e. Black cumin

Oral administration of black cumin significantly increased UV $(14.59 \mathrm{ml} / \mathrm{kg} / 24 \mathrm{~h})$ compared to controls (9.54 ml/kg/24h) (17). No significant effect on $\mathrm{UNa}^{+}$and $\mathrm{UK}^{+}$was observed (17).

\section{f. Caraway}

Aqueous extracts significantly increased UV, starting from study hour four until the 24-hour time point (5.7 and $12.8 \mathrm{ml}$, respectively) compared to controls ( 3 and $7.7 \mathrm{ml}$, respectively) (56). Twentyfour-hour $\mathrm{UNa}^{+}$and $\mathrm{UK}^{+}$excretion were significantly higher in the caraway group compared to the 
control group and reference (furosemide) group (56). Chronic administration significantly increased UV from study day 1 through study day $6\left(9.3 \mathrm{ml}\right.$ to $20.2 \mathrm{ml}$ ) versus controls $(5.4 \mathrm{ml}$ to $5.8 \mathrm{ml})$. $\mathrm{UNa}^{+}$ excretion significantly increased from study day 4 through study day 8 (56).

g. Garlic

$\mathrm{N}$-butanol fractions of fresh garlic bulbs rendered a dose-dependent diuretic effect $(9.3 \mathrm{~mL} / 5 \mathrm{~h})$ compared to controls (5.5 mL/5h) (57). $\mathrm{UNa}^{+}$excretion was significantly increased compared to controls.

h. Saffron

Aqueous extracts significantly increased UV (from 18.63 to $28.39 \mathrm{~mL} / 5 \mathrm{~h}$ ) compared to controls (8.23 $\mathrm{mL} / 5 \mathrm{~h}$ ) (58). At the highest dose, $\mathrm{UNa}^{+}$excretion was significantly increased compared to controls and the reference (hydrochlorothiazide) group. $\mathrm{UK}^{+}$excretion was significantly decreased with the lowest dose, but increased at the highest dose compared to controls.

i. Java tea

Aqueous extracts significantly increased UV in a dose-dependent manner $(7.87-16.60 \mathrm{ml} / \mathrm{kg} / 4 \mathrm{~h})$ compared to controls $(1.07 \mathrm{ml} / \mathrm{kg} / 4 \mathrm{~h})(59)$. UNa ${ }^{+}$was not significantly affected and $\mathrm{UK}^{+}$excretion significantly increased (59). Single-dose methanol extracts significantly increased $\mathrm{UNa}^{+}$and $\mathrm{UK}^{+}$ excretion without affecting UV (60). Chronic ingestion significantly increased UV beginning on study day 3; UNa+ excretion beginning on study day 4; and $\mathrm{UK}^{+}$excretion starting on study day 2 (60).

\section{d. Honey}

In animal studies, honey administration significantly increased the UV $(11,61,62), \mathrm{UNa}^{+}(11,62), \mathrm{UK}^{+}$ (62), and $\mathrm{UCl}^{-11}$ (1) excretion.

\section{DISCUSSION}

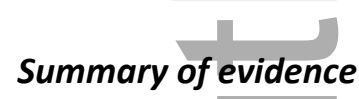

High dietary sodium, as well as wine, spirits, and high-caffeine coffee, caffeinated energy drinks, increased UV in human studies. Conversely, decreased UV was associated with low dietary sodium and consumption of milk, orange juice, and high-salt/high-sugar drinks. Cola, diet cola, sports drinks, yoghurt drinks, and tea had a diuretic effect similar to that of water. Consuming meat meal (beef) compared to an equivalent amount of sodium and water, significantly increased urinary sodium excretion, but not urine flow in healthy men. In animal studies, a variety of fruits, vegetables, herbs, spices, and honey were associated with increased UV, whereas aniseed oil decreased UV.

This article is protected by copyright. All rights reserved 


\section{Explanatory Hypotheses}

UV is predicated on a complex interplay between dietary water, solute load, and renal handling of these substances in response to a wide variety of diverse neuroendocrine inputs (Supplementary 3).

Food composition, especially macronutrient load and electrolyte concentration, influence the rate of gastric emptying, and the digestion, and intestinal absorption of nutrients, and thus may indirectly affect UV and fluid homeostasis (29). Dietary food is the predominant source of electrolytes and other osmotically active substances which are central to renal free water and solute handling and thus directly mediate UV (4,63-65). Moreover, UV may also be influenced by dietary protein intake, via the well-described processes of glomerular hyper-filtration and natriuresis which occur following a large dietary protein load $(35,64,66)$ (and thought to be mediated by variations in post-prandial vasopressin, glucagon, prostaglandins, nitric oxide, dopamine, and the renin-angiotensin system axis) $(64,66)$. The diuretic effects of alcohol are thought to be due to the suppression of vasopressin by ethanol $(34,67)$. Caffeine is believed to induce diuresis and natriuresis through a reduction in fractional sodium reabsorption at the proximal tubules (39) and distal nephron (29). Bioactive phytochemicals may be associated with a broad range of physiologic mechanisms, including flavonoids and caffeic acid derivatives in java tea extracts (60), upregulation of the on $\mathrm{Na}^{+}-\mathrm{K}^{+}$ATPase by aniseed oil $(55)$, or rather inhibition of the $\mathrm{Na}^{+}-\mathrm{K}^{+}$ATPase by parsley and garlic $(52,68)$.

\section{Importance and Limitations}

The selected studies were collectively characterized by significant heterogeneity-particularly in study design and primary outcomes-which precluded a quantitative analysis. The majority of included studies were performed on otherwise healthy adult males yet UV may be influenced by inter-individual differences in nutritional and hydration status, physical activity, dietary habits, renal function, and systemic comorbidities. Thus, findings may not be completely generalizable to other populations - particularly those with a high burden of comorbid conditions. The present study was limited to select the articles published in English language. Despite these limitations, the present analysis was the first systematic review to evaluate the effect of specific foods, food constituents, and drinks on UV. The risk of bias across selected studies was evaluated using standardized instruments in order to facilitate transparent appraisal of the available data. Furthermore, excess urine production is not simply a urological disorder, but rather a complex and multifactorial condition, and may be the presenting symptom of a wide range of hypervolemic states and other serious systemic conditions. Accordingly, we believe that our article will be of interest to a diverse readership.

\section{Implementation and Future research}

This article is protected by copyright. All rights reserved 
The of literature, amassed through the search process, includes a diverse array of human and clinically relevant animal studies which may provide the foundation for future human studies research and more refined guidelines for the role of specific foods and drinks in the management of polyuria.

A growing body of evidence, including several animal studies reported in the present systematic review, has refined and extended the concept of a diuretic index to more objectively appraise diuretic activity (11-17). Specifically, the diuretic index is defined as ratio of urine excretion in a test group to a control group, wherein substances with a diuretic index $>1.5$, between 1-1.5, 0.72-1, and $<0.72$ have been described as having "good," "moderate," "mild," and "minimal/absent" diuretic activity, respectively (15). Based on this assessment, food items such as wild raspberry (12), goji berries (13), moringa (15), black cumin (17), and Tulkarm honey (11) have shown good diuretic activity in animal studies. Importantly, recent research suggests that a similar measure, the "beverage hydration index", may be valid when used in research involving human subjects (30). Analogous to the glycaemic index used to characterize blood glucose response to specific foods (wherein pure glucose is used to as a reference values) (69), a diuretic Index may potentially be incorporated in food composition databases, and thus directly contribute to dietary counselling for polyuria and other disorders of volume homeostasis (Figure 2).

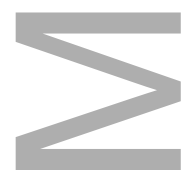

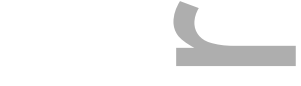 \\ CONCLUSION}

The present study provides is a state-of-the-art review on the scientific evidence of the role of food and nutrients on UV. Current evidence suggests that several types of food and drinks may impact body fluid metabolism but the quality of these data is variable. Urine production appears to be influenced by multiple factors including composition (i.e., water, macronutrients, and electrolytes), metabolite load, and the presence of specific diuresis-promoting substances (e.g., caffeine and alcohol) and other bioactive phytochemicals. Future research is needed to confirm current evidence and further explore the physiologic mechanisms underlying these findings.

This article is protected by copyright. All rights reserved 


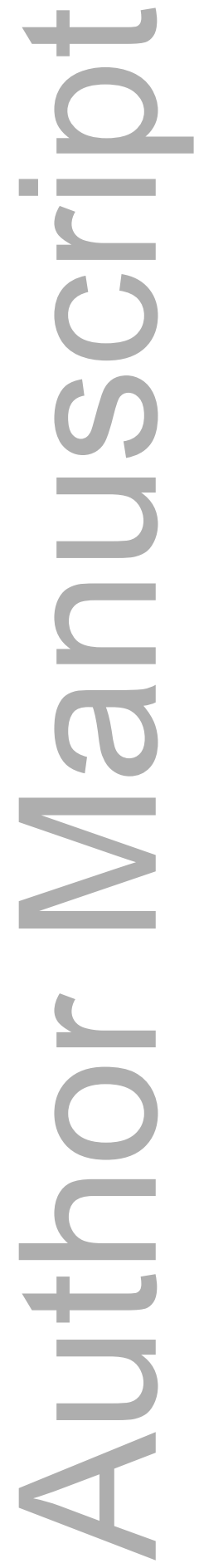

This article is protected by copyright. All rights reserved 


\section{REFERENCES}

1. Hashim H, Blanker MH, Drake MJ, Djurhuus JC, Meijlink J, Morris V, Petros P, Wen JG, Wein A. International Continence Society (ICS) report on the terminology for nocturia and nocturnal lower urinary tract function. Neurourol Urodyn. 2019;38:499-508.

2. Weiss JP. Nocturia: focus on etiology and consequences. Rev Urol. 2012;14(3-4):48-55.

3. Perrier E, Rondeau P, Poupin M, Le Bellego L, Armstrong LE, Lang F, Stookey J, Vergne S, Klein A. Relation between urinary hydration biomarkers and total fluid intake in healthy adults. Eur J Clin Nutr. 2013;67(9):939-943.

4. EFSA Panel on Dietetic Products, Nutrition, and Allergies (NDA). Scientific Opinion on Dietary reference values for water. EFSA J. 2010;8(3):1459.

5. Gupta VK, Arya V. A review on potential diuretics of Indian medicinal plants. J Chem Pharm Res. 2011;3(1):613-20.

6. Kasote DM, Jagtap SD, Thapa D, Khyade MS, Russell WR. Herbal remedies for urinary stones used in India and China: A review. J Ethnopharmacol. 2017;203:55-68.

7. Shoja MM, Tubbs RS, Bosmia AN, Fakhree MAA, Jouyban A, Balch MW, Loukas M, Khodadoust K, Khalili M, Eknoyan G. Herbal Diuretics in Medieval Persian and Arabic Medicine. J Altern Complement Med. 2015;21:309-20.

8. Everaert K, Hervé F, Bosch R, Dmochowski R, Drake M, Hashim H, Chapple C, Kerrebroeck PV, Mourad S, Abrams P, Wein A. International Continence Society consensus on the diagnosis and treatment of nocturia. Neurourol Urodyn. 2019;38(2):478-98.

9. Oelke $M$, Anderson P, Wood R, Holm-Larsen T. Nocturia is often inadequately assessed, diagnosed and treated by physicians: results of an observational, real-life practice database containing 8659 European and US-American patients. Int J Clin Pract. 2016;70(11):940-9

10. EFSA Panel on Dietetic Products, Nutrition and Allergies (NDA). Scientific Opinion on the substantiation of health claims related to various food(s)/food constituent(s) claiming an increase in renal water elimination, "kidneys health", "urinary health", "bladder health", "health of lower urinary tract", "blood health", "elimination", "urinary system benefits" and/or "supports/promotes the excretory function of the kidney", and treatment/prevention of renal gravel/kidney stones and urinary tract infections pursuant to Article 13(1) of Regulation (EC) No 1924/2006. EFSA J. 2010;8(10):1742.

11. Imtara H, Al-Waili N, Bakour M, Al-Wail W, Lyoussi B. Evaluation of antioxidant, diuretic, and wound healing effect of Tulkarm honey and its effect on kidney function in rats. Vet World. 2018;11(10):1491-9.

This article is protected by copyright. All rights reserved 
12. Zhang $Y$, Zhang $Z$, Yang $Y, Z u X$, Guan D, Wang Y. Diuretic activity of Rubus idaeus $L$ (Rosaceae) in rats. Trop J Pharm Res. 2011;10(3):243-8.

13. Pai GP, Habeeba U, Ramya K, Pradeepthi MS, Belagali Y. Evaluation of diuretic effect of Lycium barbarum Linn. (Goji Berry) in rats. Int J Pharm Sci Res. 2014;5(4):1411-15.

14. Amuthan A, Chogtu B, Bairy KL, Sudhakar, Prakash M. Evaluation of diuretic activity of Amaranthus spinosus Linn. aqueous extract in Wistar rats. J Ethnopharmacol. 2012;140(2):424-7.

15. Fekadu N, Basha H, Meresa A, Degu S, Girma B, Geleta B. Diuretic activity of the aqueous crude extract and hot tea infusion of Moringa stenopetala (Baker f.) Cufod. leaves in rats. J Exp Pharmacol. 2017;9:73-80.

16. Rao KNV, Ch S, Banji D, Sandhya S, Shwetha D,Krishna M. Diuretic activity on different extracts and formulation on aerial parts of Rumex vesicarius. Linn. J Chem Pharm Res. 2011;3(6):400-8.

17. Toma CC, Olah NK, Vlase L, Mogoşan C, Mocan A. Comparative studies on polyphenolic composition, antioxidant and diuretic effects of nigella sativa L. (black cumin) and nigella damascena L. (Lady-in-a-Mist) seeds. Molecules. 2015;20(6):9560-9574.

18. Moher D, Liberati A, Tetzlaff J, Altman DG. Preferred reporting items for systematic reviews and meta-analyses: the PRISMA statement. PLos Med 6:e1000097.

19. Higgins JPT, Sterne JAC, Savović J, et al. A revised tool for assessing risk of bias in randomized trials In: Chandler J, McKenzie J, Boutron I, Welch V (editors). Cochrane Methods. Cochrane Database of Systematic Reviews 2016, Issue 10 (Suppl 1).

20. Hooijmans $C R$, Rovers $M M$, de Vries RB, Leenaars $M$, Ritskes-Hoitinga $M$, Langendam MW . SYRCLE's risk of bias tool for animal studies. BMC Med Res Methodol. 2014;14(10):43.

21. Heyne N, Benöhr P, Mühlbauer B, Delabar U, Risler T, Osswald H. Regulation of renal adenosine excretion in humans - Role of sodium and fluid homeostasis. Nephrol Dial Transplant. 2004;19(11):2737-2741.

22. Palacios C, Wigertz K, Martin BR, Jackman L, Pratt JH, Peacock M, McCabe G, Weaver CM. Sodium retention in black and white female adolescents in response to salt intake. J Clin Endocrinol Metab. 2004;89(4):1858-1863.

23. Luippold G, Benöhr P, Piesch C, Heyne N, Mühlbauer B. Urinary dopamine excretion in healthy volunteers: Effect of sodium diet and acute water load. Pflugers Arch Eur J Physiol. 2000;440(1):28-33

24. Cuzzola F, Mallamaci F, Tripepi G, Parlongo S, Cutrupi S, Cataliotti A, Stancanelli B, Malatino L, Bellanuova I, Ferri C, et al. Urinary adrenomedullin is related to ET-1 and salt intake in patients with mild essential hypertension. Am J Hypertens. 2001;14(3):224-30

This article is protected by copyright. All rights reserved 
25. Rakova N, Kitada K, Lerchl K, Dahlmann A, Birukov A, Daub S, Kopp C, Pedchenko T, Zhang Y, Beck $L$, et al. Increased salt consumption induces body water conservation and decreases fluid intake. J Clin Invest. 2017;127(5):1932-43.

26. Anderson D, Fedorova OV, Morrell CH, Longo DL, Kashkin VA, Metzler JD, Bagrov AY, Lakatta EG. Endogenous Sodium Pump Inhibitors and Age-associated Increases in Salt Sensitivity of Blood Pressure in Normotensives. Am J Physiol Regul Integr Comp Physiol. 2008;294(4):R1248-54.

27. He FJ, Markandu ND, Sagnella GA, MacGregor GA. Effect of salt intake on renal excretion of water in humans. Hypertension. 2001;38:317-320.

28. Yatabe MS, Iwahori T, Watanabe A, Takano K, Sanada H, Watanabe T, Ichihara A, Felder RA, Miura $\mathrm{K}$, Ueshima $\mathrm{H}$, et al. Urinary sodium-to-potassium ratio tracks the changes in salt intake during an experimental feeding study using standardized low-salt and high-salt meals among healthy japanese volunteers. Nutrients. 2017;9:951.

29. Maughan RJ, Watson P, Cordery PAA, Walsh NP, Oliver SJ, Dolci A, Rodriguez-Sanchez N, Galloway SDR. Sucrose and sodium but not caffeine content influence the retention of beverages in humans under euhydrated conditions. Int J Sport Nutr Exerc Metab. 2019;29:51-60.

30. Maughan RJ, Watson P, Cordery PAA, Walsh NP, Oliver SJ, Dolci A, Rodriguez-Sanchez N, Galloway SDR. A randomized trial to assess the potential of different beverages to affect hydration status: Development of a beverage hydration index. Am J Clin Nutr. 2016;103:717723.

31. Seery S, Jakeman P. A metered intake of milk following exercise and thermal dehydration restores whole-body net fluid balance better than a carbohydrate-electrolyte solution or water in healthy young men. Br J Nutr. 2016;116(6):1013-1021.

32. Bakali E, Hong J, Gillespie J, Tincello D. Saccharin increases perception of bladder filling in a forced diuresis experiment. Neurourol Urodyn. 2017;36(5):1363-1368.

33. Polhuis KCMM, Wijnen AHC, Sierksma A, Calame W, Tieland M. The diuretic action of weak and strong alcoholic beverages in elderly men: A randomized diet-controlled crossover trial. Nutrients. 2017;9(7):660.

34. Jiménez-Pavón D, Cervantes-Borunda MS, Díaz LE, Marcos A, Castillo MJ. Effects of a moderate intake of beer on markers of hydration after exercise in the heat: A crossover study. J Int Soc Sports Nutr. 2015;12(1):26.

35. Hostetter TH. Human renal response to a meat meal. Am J Physiol. 1986;250(4):F613-8.

36. Niksefat M, A-Fakhrabadi M, Mousavi Z, Ziaee V, Fallah J Memari AH. Yogurt drink effectively rehydrates athletes after a strenuous exercise session. Acta Medica Bulg. 2019;46(1):43-49. 
37. Nussberger J, Mooser V, Maridor G, Juillerat L, Waeber B, Brunner HR. Caffeine-induced diuresis and atrial natriuretic peptides. J Cardiovasc Pharmacol. 1990;15:685-691.

38. Killer SC, Blannin AK, Jeukendrup AE. No evidence of dehydration with moderate daily coffee intake: A counterbalanced cross-over study in a free-living population. PLoS One. 2014;9(1):e84154.

39. Seal AD, Bardis CN, Gavrieli A, Grigorakis P, Adams JD, Arnaoutis G, Yannakoulia M, Kavouras SA. Coffee with High but Not Low Caffeine Content Augments Fluid and Electrolyte Excretion at Rest. Front Nutr. 2017;4:40.

40. Peerapen P, Ausakunpipat N, Sutthimethakorn S, Aluksanasuwan S, Vinaiphat A, Thongboonkerd V. Physiologic changes of urinary proteome by caffeine and excessive water intake. Clin Chem Lab Med. 2017;55(7):993-1002.

41. Riesenhuber A, Boehm M, Posch M, Aufricht C. Diuretic potential of energy drinks. Amino Acids. 2006;31(1):81-83.

42. Ishihara K, Kato Y, Usami A, Yamada M, Yamamura A, Fushiki T, Seyma Y. Electrolyte-free milk protein solution influences sodium and fluid retention in rats. J Nutr Sci. 2013;2:1-7.

43. Galati EM, Tripodo MM, Trovato A, Miceli N, Monforte MT. Biological effect of Opuntia ficus indica (L.) Mill. (Cactaceae) waste matter. Note I: Diuretic activity. J Ethnopharmacol. 2002;79(1):17-21.

44. Vargas Solis R, Perez Gutierrez RM. Diuretic and urolithiatic activities of the aqueous extract of the fruit of Randia echinocarpa on rats. J Ethnopharmacol. 2002;83(1-2):145-7.

45. Shah AP, Patel SB, Patel KV, Gandhi TR. Effect of Citrus medica Linn. in urolithiasis induced by ethylene glycol model. Iran J Pharmacol Ther. 2014;13(1):35-39.

46. Alarcón-Alonso J, Zamilpa A, Aguilar FA, Herrera-Ruiz M, Tortoriello J, Jimenez-Ferrer E. Pharmacological characterization of the diuretic effect of Hibiscus sabdariffa Linn (Malvaceae) extract. J Ethnopharmacol. 2012;139(3):751-756.

47. Gasparotto Junior A, Prando TBL, Leme TDSV, Leme TDSV, Gasparotto FM, Loureno ELB, Rattmann YD, Silva-Santos JED, Kassuya CAL, Marwues MCA. Mechanisms underlying the diuretic effects of Tropaeolum majus L. extracts and its main component isoquercitrin. J Ethnopharmacol. 2012;141(1):501-509.

48. Zhang G, Zeng X, Han L, Wei JA, Huang H. Diuretic activity and kidney medulla AQP1, AQP2, $A Q P 3, V 2 R$ expression of the aqueous extract of sclerotia of Polyporus umbellatus FRIES in normal rats. J Ethnopharmacol. 2010;128(2):433-437.

49. Vargas Solis R, Perez Gutierrez RM, Perez S, Zavala MA, Perez C. Antiurolithiatic activity of Raphanus sativus aqueous extract on rats. J Ethnopharmacol. 1999;68(1-3):335-338.

This article is protected by copyright. All rights reserved 
50. Angappan R, Devanesan AA, Thilaga S. Diuretic effect of chlorogenic acid from traditional medicinal plant Merremia emarginata (Burm. F.) and its by product hippuric acid. Clin Phytoscience. 2018;4(1):29.

51. Gilani AH, Jabeen $Q$, Khan AU, Shah AJ. Gut modulatory, blood pressure lowering, diuretic and sedative activities of cardamom. J Ethnopharmacol. 2008;115(3):463-472.

52. Kreydiyyeh SI, Usta J. Diuretic effect and mechanism of action of parsley. J Ethnopharmacol. 2002;79(3):353-7.

53. Vranješ M, Popović BM, Štajner D, Ivetić V, Mandić A, Vranješ D. Effects of bearberry, parsley and corn silk extracts on diuresis, electrolytes composition, antioxidant capacity and histopathological features in mice kidneys. J Funct Foods. 2016;21:272-82.

54. Haloui M, Louedec L, Michel JB, Lyoussi B. Experimental diuretic effects of Rosmarinus officinalis and Centaurium erythraea. J Ethnopharmacol. 2000;71(3):465-72.

55. Kreydiyyeh SI, Usta J, Knio K, Markossian S, Dagher S. Aniseed oil increases glucose absorption and reduces urine output in the rat. Life Sci. 2003;74(5):663-73.

56. Lahlou S, Tahraoui A, Israili Z, Lyoussi B. Diuretic activity of the aqueous extracts of Carum carvi and Tanacetum vulgare in normal rats. J Ethnopharmacol. 2007;110(3):458-63.

57. Tiwari S, Sirohi B, Bigoniya P. Phytochemical screening and diuretic activity of Allium sativum steroidal and triterpenoid saponin fraction. Int J Pharm Sci Res. 2012;3(9):3354-61.

58. Shariatifar N, Shoeibi S,Sani MJ, Jamshidi AH, Zarei A, Mehdizade A, Dadgarnejad M. Study on diuretic activity of saffron (stigma of Crocus sativus L.) Aqueous extract in rat. J Adv Pharm Technol Res. 2014;5(1):17-20.

59. Adam Y, Somchit MN, Sulaiman MR, , Nasaruddin AA, Zuraini A, Bustamam AA, Zakaria ZA. Diuretic properties of Orthosiphon stamineus Benth. J Ethnopharmacol. 2009;124(1):154-8.

60. Arafat OM, Tham SY, Sadikun A, Zhari I, Haughton PJ, Asmawi MZ. Studies on diuretic and hypouricemic effects of Orthosiphon stamineus methanol extracts in rats. J Ethnopharmacol. 2008;118(3):354-60.

61. El-Guendouz S, Al-Waili N, Aazza S, Elamine Y, Zizi S, Al-Waili T, Al-Waili A, Lyoussi B. Antioxidant and diuretic activity of co-administration of Capparis spinosa honey and propolis in comparison to furosemide. Asian Pac J Trop Med. 2017;10(10):974-80.

62. El-Haskoury R, Zizi S, Touzani S, Al-Waili N, Al-Ghamdi A, Lyoussi B. Diuretic activity of carob (Ceratonia siliqua L.) honey: Comparison with furosemide. African J Tradit Complement Altern Med. 2015;12(4):128-33.

63. Bhasin B, Velez JCQ. Evaluation of Polyuria: The Roles of Solute Loading and Water Diuresis. Am J Kidney Dis. 2016;67(3):507-511. 
64. Bankir L, Roussel R, Bouby N. Protein- and diabetes-induced glomerular hyperfiltration: Role of glucagon, vasopressin, and urea. Am J Physiol Ren Physiol. 2015;309(1):F2-F23.

65. Seifter JL. Body Fluid Compartments, Cell Membrane Ion Transport, Electrolyte Concentrations, and Acid-Base Balance. Semin Nephrol. 2019;39(4):368-379.

66. Krishna GG, Newell G, Miller E, Heeger P, Smith R, Polansky M, Kapoor S, Hoeldtke R. Proteininduced glomerular hyperfiltration: Role of hormonal factors. Kidney Int. 1988;33(2):578583.

67. Hobson RM, Maughan RJ. Hydration status and the diuretic action of a small dose of alcohol. Alcohol Alcohol. 2010;45(4):366-373.

68. Pantoja C V., Martín NT, Norris BC, Contreras CM. Purification and bioassays of a diuretic and natriuretic fraction from garlic (Allium sativum). J Ethnopharmacol. 2000;70(1):35-40.

69. Jenkins DJ, Wolever TM, Taylor RH, et al. Glycemic index of foods: a physiological basis for carbohydrate exchange. Am J Clin Nutr. 1981;34(3):362-6.

70. Patel S. Sodium Balance - An Integrated Physiological Model and Novel Approach. Saudi J Kidney Dis Transpl. 2009;20(4):560-9.

71. Pizzorno J. Acidosis: An old idea validated by new research. Integr Med. 2015;14(1):8-12.

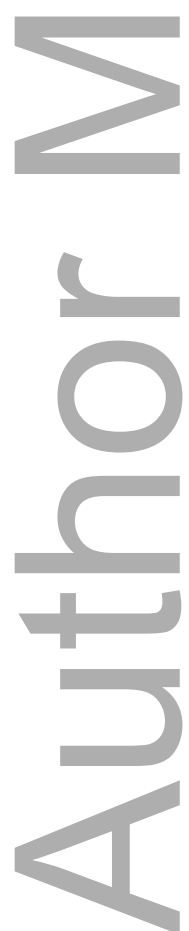

This article is protected by copyright. All rights reserved 


\section{LIST OF TABLES AND FIGURES}

Table 1. Effect of Electrolytes on Urine Volume, Urinary Sodium, and Potassium Excretion

Table 2. Effect of Osmotically Active Substances on Urine Volume, Urinary Sodium, and Potassium Excretion

Table 3. Effect of Caffeinated and Non-caffeinated Drinks on Urine Volume, Urinary Sodium, and Potassium Excretion

Table 4. Effect of Herbs, Vegetables and Fruits on Urine Volume, Urinary Sodium, Potassium and Chloride Excretion

Figure 1. Study Selection Flow Diagram

Figure 2. Proposed Experimental Plan for the Development of a Food Diuretic Index

Supplementary data 1 . Search strategy

Supplementary data 2. Bias Risk Assessment Summary

Supplementary data 3. Potential Mechanisms of Increased Diuresis

Review material. PRISMA Checklist
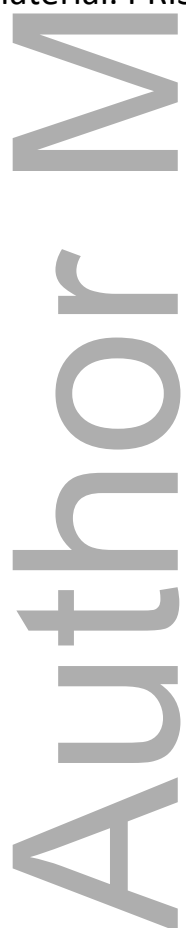

This article is protected by copyright. All rights reserved 
Table 1. Effect of Electrolytes on Urine Volume, Urinary Sodium, And Potassium Excretion

\begin{tabular}{|c|c|c|c|c|c|c|c|c|}
\hline Study & Study design & Population & Dose & Order & $\begin{array}{l}\text { Duration per } \\
\text { diet/dose }\end{array}$ & UV & $\mathrm{UNa}^{+}$ & $\mathrm{UK}^{+}$ \\
\hline SALT & & & & & & & & \\
\hline \multicolumn{9}{|l|}{ HUMAN STUDIES } \\
\hline \multirow{4}{*}{$\begin{array}{l}\text { Maughan } \\
\text { al. } 2019\end{array}$} & $\mathrm{CO} / \mathrm{R} / \mathrm{DB} / \mathrm{CT}$ & 12 euhydrated and fasted healthy & Salted water: & Random & 4 hours & & & \\
\hline & & males & $15 \mathrm{mmol} / \mathrm{L}$ & & & 0 & - & - \\
\hline & & Age: $25 \pm 4$ years & $27 \mathrm{mmol} / \mathrm{L}$ & & & 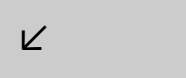 & - & - \\
\hline & & BMI: $24.6 \pm 2.2 \mathrm{~kg} / \mathrm{m}^{2}$ & $52 \mathrm{mmol} / \mathrm{L}$ & & & $k$ & - & - \\
\hline \multirow{4}{*}{$\begin{array}{l}\text { Heyne N et al. } \\
2004\end{array}$} & $\mathrm{CO} / \mathrm{R} / \mathrm{CT}$ & 12 normotensive healthy adults & Dietary salt & Random & 8 days & & & \\
\hline & & $M / F: 6 / 6$ & Low: $<5 \mathrm{~g} /$ day & & & 0 & 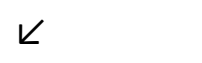 & $\pi$ \\
\hline & & Age (median): 25.5 years & High: Normal + 100 & & & 0 & $\pi$ & 0 \\
\hline & & BMI: $23.9 \pm 0.9 \mathrm{~kg} / \mathrm{m}^{2}$ & $\mathrm{mg} / \mathrm{kg} / \mathrm{day}$ & & & & & \\
\hline \multirow{4}{*}{$\begin{array}{l}\text { Palacios } \\
\text { al. } 2004\end{array}$} & $\mathrm{CO} / \mathrm{R} / \mathrm{CT}$ & 22 black girls & Dietary salt & Random & 3 weeks & & & \\
\hline & & Age: $12.4 \pm 0.3$ years & Low: $1.3 \mathrm{~g} / \mathrm{d}$ & & & 0 & $k$ & - \\
\hline & & 14 white girls & High: $4 \mathrm{~g} / \mathrm{d}$ & & & 0 & $\pi$ & - \\
\hline & & Age: $13.2 \pm 0.3$ years & & & & & & \\
\hline \multirow{4}{*}{$\begin{array}{l}\text { Cuzzola } \\
2001\end{array}$} & $\mathrm{CO} / \mathrm{R} / \mathrm{CT} / \mathrm{DB}$ & 55 adults with mild essential & Dietary salt & Random & 2 weeks & - & - & - \\
\hline & & hypertension & Low: 50 mmol/day & & & $\pi($ Only in & $\pi$, (Only in & \\
\hline & & $\mathrm{M} / \mathrm{F}: 41 / 14$ & High: 150 & & & highest & highest salt & \\
\hline & & Age: $47.0 \pm 9.9$ years & $\mathrm{mmol} / \mathrm{day}$ & & & salt- & excreting & \\
\hline
\end{tabular}

This article is protected by copyright. All rights reserved 


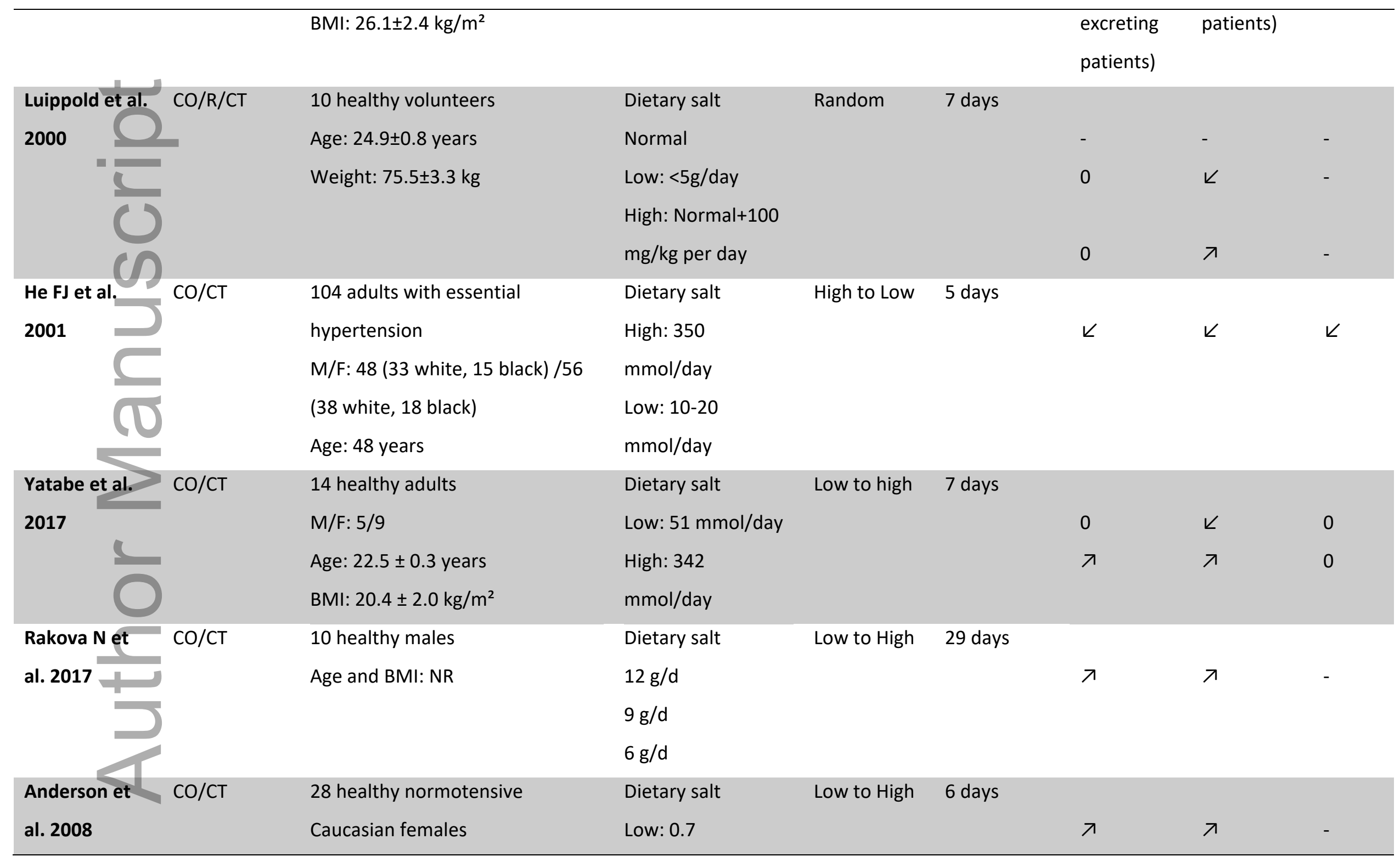

This article is protected by copyright. All rights reserved 


\begin{tabular}{|c|c|c|c|c|c|c|c|}
\hline r & $\begin{array}{l}\text { Age: } 53 \pm 1.6 \text { years } \\
\text { BMI: } 25.2 \pm 0.6 \mathrm{~kg} / \mathrm{m}^{2}\end{array}$ & $\begin{array}{l}\mathrm{mmol} / \mathrm{kg} / \text { day } \\
\text { High: } 4 \\
\mathrm{mmol} / \mathrm{kg} / \text { day }\end{array}$ & & & & & \\
\hline SPORTS DRINKS & & & & & & & \\
\hline HUMAN STUDIES & & & & & & & \\
\hline $\begin{array}{l}\text { Maughan et } \mathrm{CO} / \mathrm{R} / \mathrm{CT} \\
\text { al. } 2016\end{array}$ & $\begin{array}{l}17^{*} \text { euhydrated and fasted males } \\
\text { Age: } 24 \pm 4 \text { years } \\
\text { Weight: } 77.3 \pm 9.9 \mathrm{~kg}\end{array}$ & $\begin{array}{l}\text { Sports drink: } 1 \mathrm{~L} \\
\text { (Na: } 21 \mathrm{mmol} / \mathrm{L}, \mathrm{K}: \\
4 \mathrm{mmol} / \mathrm{L})\end{array}$ & Random & 4 hours & 0 & $K$ & $\lambda$ \\
\hline $\begin{array}{l}\text { Seery et al. CO/R/CT } \\
2016\end{array}$ & $\begin{array}{l}7 \text { healthy males } \\
\text { Age: } 26 \pm 6 \text { years, } \\
\text { Weight: } 86.4 \pm 11.5 \mathrm{~kg}\end{array}$ & $\begin{array}{l}\text { Sports drink } \\
\text { (Na: } 21 \mathrm{mmol} / \mathrm{L} \text {, } \\
\mathrm{K}: 4 \mathrm{mmol} / \mathrm{L}): \\
2.8 \pm .56 \mathrm{~L}\end{array}$ & Random & 5 hours & 0 & - & - \\
\hline ANIMAL STUDIES & & & & & & & \\
\hline $\begin{array}{l}\text { Ishihara et al. CT } \\
2013\end{array}$ & $\begin{array}{l}\text { 18* male Wistar rats } \\
\text { Age (mean): } 8 \text { weeks } \\
\text { Weight (range): } 200-250 \mathrm{~g}\end{array}$ & $\begin{array}{l}\text { Sports drink (Na: } \\
19.5 \mathrm{mmol} / \mathrm{L}, \mathrm{K}: 5 \\
\mathrm{mmol} / \mathrm{L} \text { ): } 6 \mathrm{ml}\end{array}$ & - & 4 hours & 0 & 0 & 0 \\
\hline
\end{tabular}

CO: crossover, R: randomized, CT: control SB: single-blinded, DB: double-blinded, M/F: male/female, BMI: Body mass index, UV: urinary volume, UNa+: urinary sodium, $\mathrm{UK}^{+}$: urinary potassium, - : not reported, 0 : no significant effect, $\nearrow$ : significant increase, $\swarrow$ : significant decrease, $*$ : number of subjects/animals per test group. Data are reported as mean \pm standard deviation unless otherwise specified.

This article is protected by copyright. All rights reserved 
Table 2. Effect of Osmotically Active Substances on Urine Volume, Urinary Sodium, And Potassium Excretion

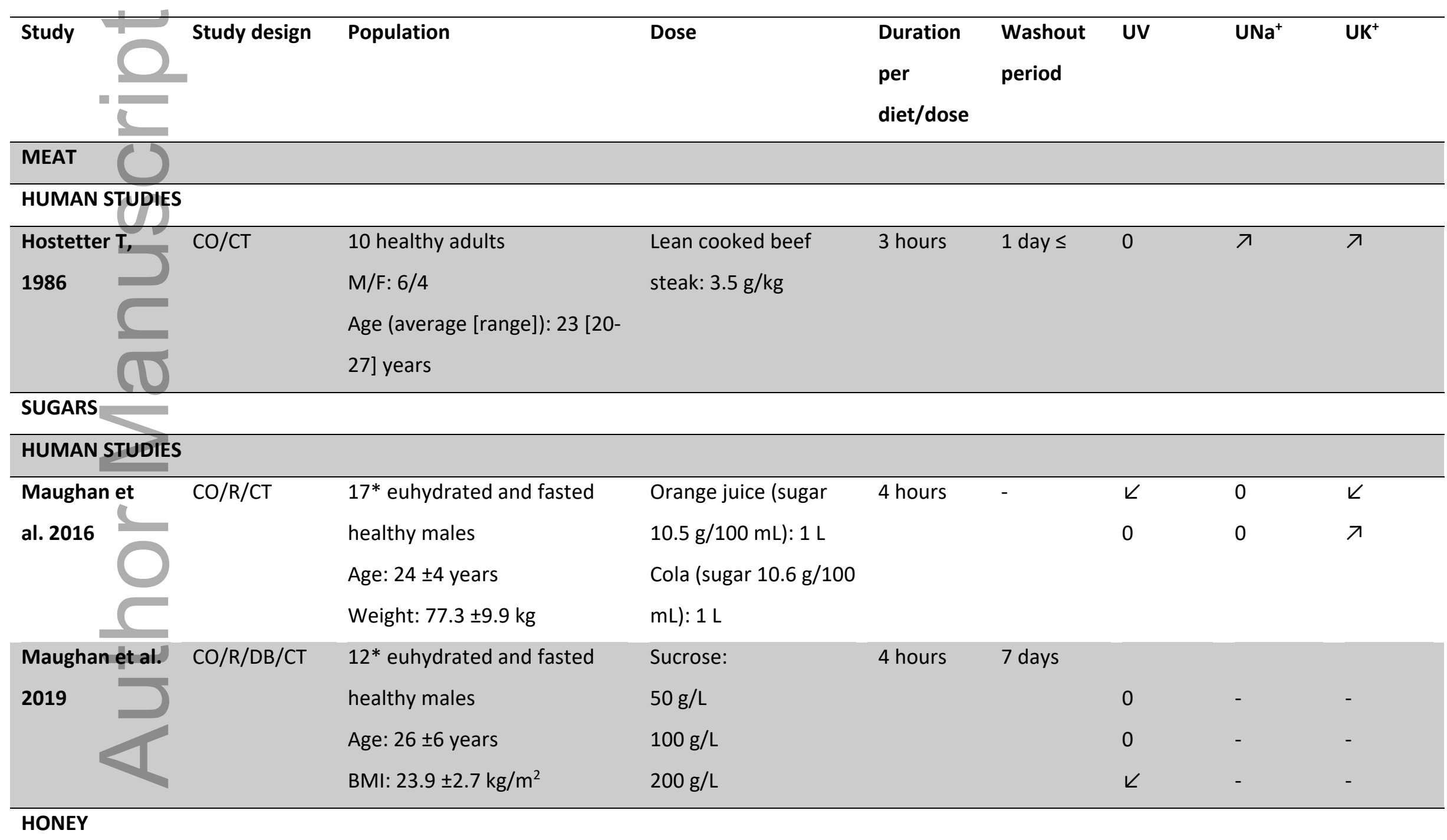

This article is protected by copyright. All rights reserved 


\begin{tabular}{|c|c|c|c|c|c|c|c|c|}
\hline \multicolumn{9}{|c|}{ ANIMAL STUDIES } \\
\hline El-Haskoury et & $\mathrm{R} / \mathrm{CT}$ & 5 adult male Wistar rats & Carob honey: 100 & 24 hours & - & $\lambda$ & $\pi$ & オ \\
\hline al. 2015 & & Weight (range): 230-278 g & $\mathrm{mg} / \mathrm{kg}$ & 9 days & - & ス & $\lambda$ & $\pi$ \\
\hline Imtara et al. & $\mathrm{R} / \mathrm{CT}$ & 6 Wistar rats & Tulkarm honey: 100 & 24 hours & - & ス & $\pi$ & 0 \\
\hline 2018 & & Weight (range): 200-240 g & $\mathrm{mg} / \mathrm{kg}$ & 11 days & - & オ & $\pi$ & 0 \\
\hline El-Guendou & $\mathrm{CT}$ & 6 male Wistar rats & Capparis spinose & 21 days & - & $\pi$ & 0 & 0 \\
\hline al. 2017 & & Weight: $190 \pm 40 \mathrm{~g}$ & honey: 1000 mg/kg & & & & & \\
\hline \multicolumn{9}{|l|}{ SWEETENERS } \\
\hline \multicolumn{9}{|c|}{ HUMAN STUDIES } \\
\hline \multirow{3}{*}{$\begin{array}{l}\text { Bakali et al. } \\
2017\end{array}$} & $\mathrm{CO} / \mathrm{R} / \mathrm{SB} / \mathrm{CT}$ & 40 healthy women (Indian & Saccharin 5 mg/kg & 2 hours & 28 days & 0 & - & - \\
\hline & & Asian 20, Caucasian 20) & & & & & & \\
\hline & & Age (range): $20-50$ years & & & & & & \\
\hline \multirow{4}{*}{$\begin{array}{l}\text { Maughan } \\
\text { al. } 2016\end{array}$} & $\mathrm{CO} / \mathrm{R} / \mathrm{CT}$ & $16^{*}$ euhydrated and fasted & Diet cola (aspartame & 4 hours & - & 0 & 0 & 0 \\
\hline & & males & $180 \mathrm{mg} / 354 \mathrm{~mL}): 1 \mathrm{~L}$ & & & & & \\
\hline & & Age: $24 \pm 4$ years & & & & & & \\
\hline & & Weight: $77.3 \pm 9.9$ kg & & & & & & \\
\hline \multicolumn{9}{|l|}{ ALCOHOL } \\
\hline \multicolumn{9}{|c|}{ HUMAN STUDIES } \\
\hline $\begin{array}{l}\text { Jiménez-Pavón } \\
\text { et al. } 2015\end{array}$ & $\mathrm{CO} / \mathrm{R} / \mathrm{CT}$ & $\begin{array}{l}16 \text { physically active, healthy } \\
\text { males }\end{array}$ & $\begin{array}{l}\text { Beer (1.8\% alcohol): } \\
660 \mathrm{ml}\end{array}$ & 2 hours & 3 weeks & 0 & 0 & 0 \\
\hline & & Age: $21.1 \pm 1.4$ years & & & & & & \\
\hline
\end{tabular}

This article is protected by copyright. All rights reserved 


\begin{tabular}{|c|c|c|c|c|c|c|c|c|}
\hline \multicolumn{9}{|c|}{ Weight: $74.1 \pm 6.5 \mathrm{~kg}$} \\
\hline Polhuis et al. & $\mathrm{CO} / \mathrm{R} / \mathrm{CT}$ & 20 males & $30 \mathrm{~g}$ of alcohol: & 4 hours & 7 days & - & - & - \\
\hline \multirow[t]{3}{*}{2017} & & Age (median [range]): 69 [65- & Beer ( $5 \%$ alcohol) & & & 0 & 0 & 0 \\
\hline & & 75] years & wine $(13.5 \%$ alcohol) & & & $\pi$ & $K$ & $K$ \\
\hline & & Weight: $77.7 \pm 9.9 \mathrm{~kg}$ & spirits (35\% alcohol) & & & $\lambda$ & $K$ & K \\
\hline \multirow{3}{*}{$\begin{array}{l}\text { Maughan } \\
\text { al. } 2016\end{array}$} & & males & $1 \mathrm{~L}$ & & & & & \\
\hline & & Age: $24 \pm 4$ years & & & & & & \\
\hline & & Weight: $77.3 \pm 9.9 \mathrm{~kg}$ & & & & & & \\
\hline
\end{tabular}

CO: crossover, R: randomized, CT: control/placebo SB: single blinded, DB: double blinded, M/F: male/female, BMI: body mass index, UV: urinary volume, $\mathrm{UNa}^{+}$: urinary sodium, $\mathrm{UK}^{+}$: urinary potassium, - : not reported, 0 : no significant effect, $\lambda$ : significant increase, $\measuredangle:$ significant decrease, *: number of subjects/animals per test group. Unless otherwise specified, the data are expressed as mean \pm standard deviation.

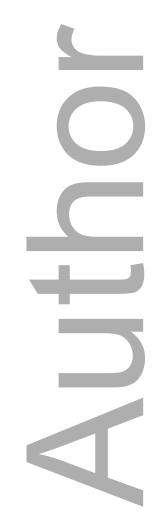

This article is protected by copyright. All rights reserved 
Table 3. Effect of Caffeinated and Non-caffeinated Drinks On Urine Volume, Urinary Sodium And Potassium Excretion

\begin{tabular}{|c|c|c|c|c|c|c|c|c|}
\hline Study & Study design & Population & Dose & Order & $\begin{array}{l}\text { Duration per } \\
\text { diet/dose }\end{array}$ & UV & $\mathrm{UNa}^{+}$ & $\mathrm{UK}^{+}$ \\
\hline \multicolumn{9}{|c|}{ CAFFEINATED DRINKS: COFFEE } \\
\hline \multicolumn{9}{|c|}{ HUMAN STUDIES } \\
\hline $\begin{array}{l}\text { Nussberger et al. } \\
1990\end{array}$ & $\mathrm{CO} / \mathrm{R} / \mathrm{SB} / \mathrm{CT}$ & $\begin{array}{l}8 \text { healthy males } \\
\text { Age (range): } 24-28 \text { years }\end{array}$ & $\begin{array}{l}\text { Coffee: } 250 \mathrm{mg} \\
\text { caffeine }\end{array}$ & Random & 3 hours & 0 & $\lambda$ & 0 \\
\hline Killer et al. 2014 & $\mathrm{CO} / \mathrm{CT}$ & $\begin{array}{l}50 \text { healthy males } \\
\text { Age: } 28.1 \pm 7.3 \text { years } \\
\text { Weight: } 77.0 \pm 12.1 \mathrm{~kg}\end{array}$ & $\begin{array}{l}\text { Coffee: caffeine } 4 \\
\mathrm{mg} / \mathrm{kg}\end{array}$ & Random & 3 days & 0 & $\pi$ & - \\
\hline $\begin{array}{l}\text { Maughan et } \\
\text { al. } 2016\end{array}$ & $\mathrm{CO} / \mathrm{R} / \mathrm{CT}$ & $\begin{array}{l}17 * \text { euhydrated and } \\
\text { fasted males } \\
\text { Age: } 24 \pm 4 \text { years } \\
\text { Weight: } 77.3 \pm 9.9 \mathrm{~kg}\end{array}$ & $\begin{array}{l}\text { Coffee: caffeine } 212 \\
\mathrm{mg} / \mathrm{L}\end{array}$ & Random & 4 hours & 0 & $\pi$ & 0 \\
\hline Seal et al. 2017 & $\mathrm{CO} / \mathrm{SB} / \mathrm{CT}$ & $\begin{array}{l}10 \text { healthy adults } \\
\text { M/F: } 8 / 2 \\
\text { Age: } 27 \pm 5 \text { years } \\
\text { BMI } 29.1 \pm 4.4 \mathrm{~kg} / \mathrm{m}^{2}\end{array}$ & $\begin{array}{l}\text { Coffee: } \\
\text { low caffeine } 3 \mathrm{mg} / \mathrm{kg} \\
\text { high caffeine } 6 \\
\mathrm{mg} / \mathrm{kg}\end{array}$ & $\begin{array}{l}\text { Low to } \\
\text { High }\end{array}$ & 3 hours & $\begin{array}{l}0 \\
\nearrow\end{array}$ & $\begin{array}{l}0 \\
\nearrow\end{array}$ & $\begin{array}{l}0 \\
\nearrow\end{array}$ \\
\hline $\begin{array}{l}\text { Peerapen et al. } \\
2017\end{array}$ & $\mathrm{CO} / \mathrm{CT}$ & $\begin{array}{l}30 \text { healthy adults } \\
\text { M/F: } 7 / 23 \text { Weight: } 58.0 \pm \\
14.9 \mathrm{~kg}\end{array}$ & $\begin{array}{l}\text { Coffee: } 2.75 \pm 0.54 \\
\text { mg caffeine/kg }\end{array}$ & - & 3 hours & $\pi$ & - & - \\
\hline
\end{tabular}

This article is protected by copyright. All rights reserved 


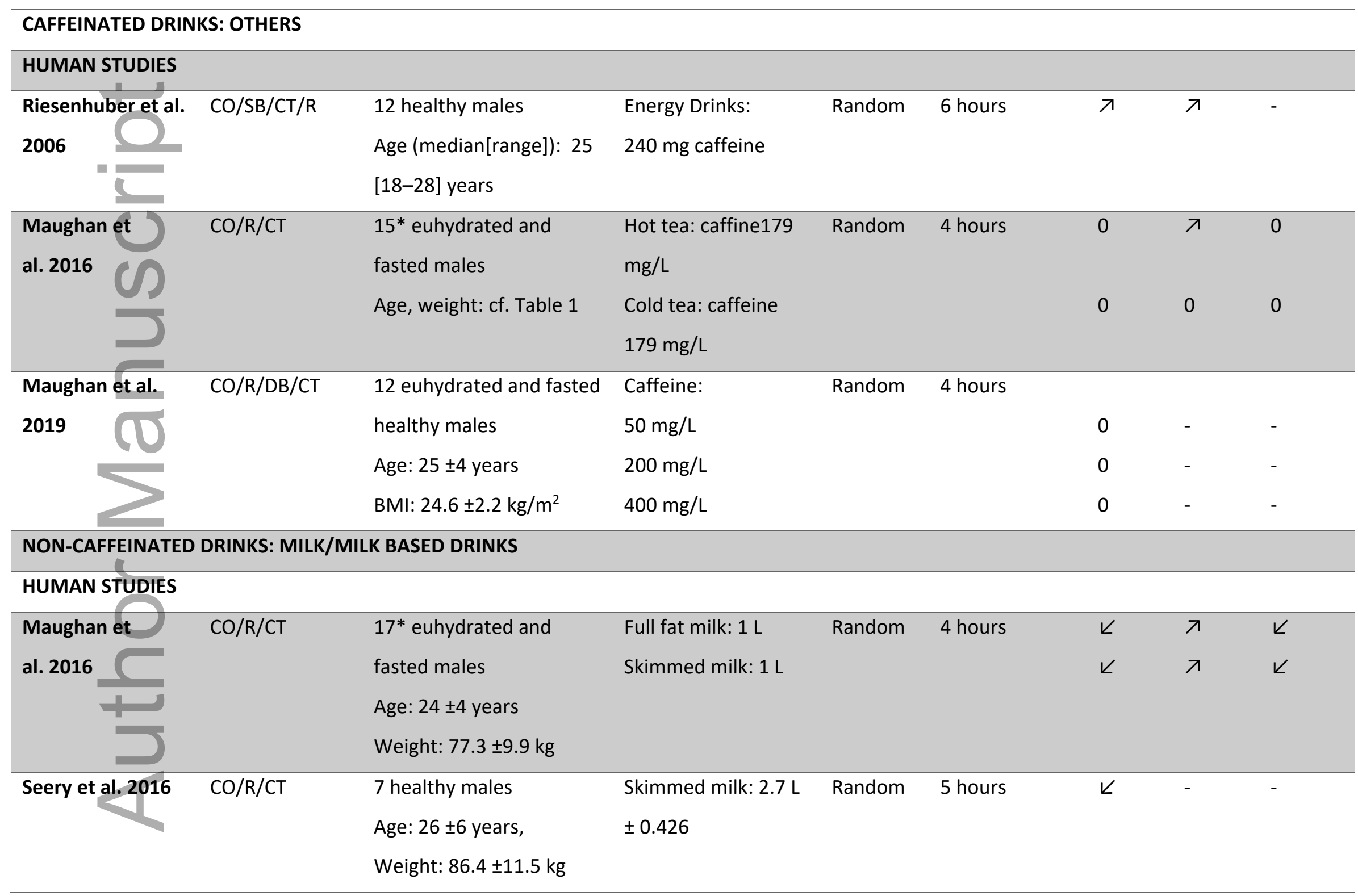

This article is protected by copyright. All rights reserved 


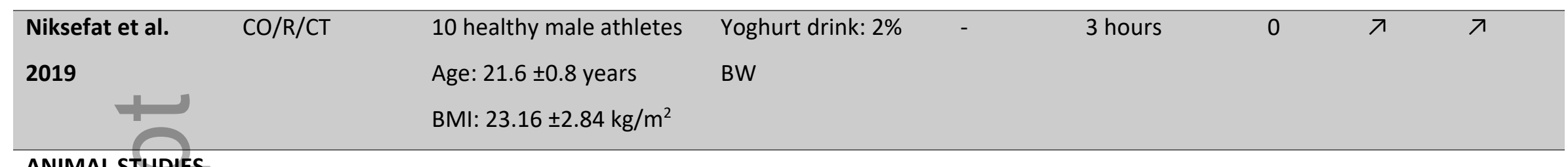

\section{ANIMAL STUDIES}

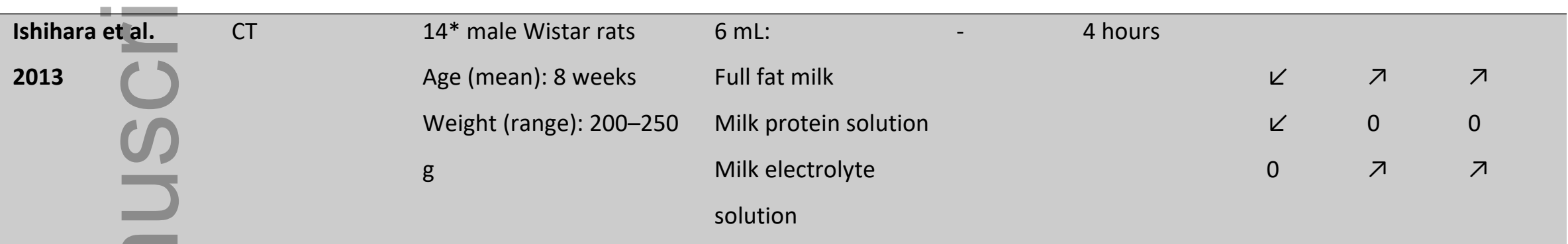

CO: crossover, R: randomized, CT: control/placebo SB: single blinded, DB: double blinded, BW: body weight, M/F: male/female, BMI: body mass index, - : not reported, UV: urinary volume, $\mathrm{UNa}^{+}$: urinary sodium, $\mathrm{UK}^{+}$: urinary potassium, 0 : no significant effect, $\nearrow$ : significant increase, $\measuredangle$ :significant decrease, $*$ : number of subjects/animals per test group. Unless otherwise specified, the data are expressed as mean \pm standard deviation.

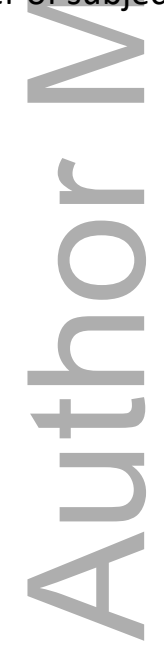

This article is protected by copyright. All rights reserved 
Table 4. Effect of Herbs, Vegetables and Fruits on Urine Volume, Urinary Sodium, Potassium and Chloride Excretion

\begin{tabular}{|c|c|c|c|c|c|c|c|c|c|}
\hline $\begin{array}{l}\text { Common name/ } \\
\text { Species }\end{array}$ & Study & $\begin{array}{l}\text { Study } \\
\text { design }\end{array}$ & Population & Dose & $\begin{array}{l}\text { Duration } \\
\text { per } \\
\text { diet/dose }\end{array}$ & UV & $\mathrm{UNa}^{+}$ & $\mathrm{UK}^{+}$ & $\mathrm{UCl}^{-}$ \\
\hline \multicolumn{10}{|l|}{ HERBS/SPICES } \\
\hline \multicolumn{10}{|l|}{ ANIMAL STUDIES } \\
\hline \multirow{2}{*}{$\begin{array}{l}\text { Parsley } \\
\text { Petroselinum } \\
\text { crispum/ sativum }\end{array}$} & $\begin{array}{l}\text { Kreydiyyeh et } \\
\text { al. } 2002\end{array}$ & $\mathrm{CT}$ & $\begin{array}{l}6 \text { male Sprague-Dawley rats } \\
\text { Weight (range): } 150-200 \mathrm{~g}\end{array}$ & $\begin{array}{l}\text { Aqueous extract: } \\
20 \mathrm{~g} / 100 \mathrm{ml}\end{array}$ & 24 hours & $\pi$ & - & - & - \\
\hline & $\begin{array}{l}\text { Vranješ et al. } \\
2016\end{array}$ & $\mathrm{R} / \mathrm{CT}$ & $\begin{array}{l}10 \text { Mus musculus albino rats } \\
\text { age }<3 \text { months } \\
\text { Weight (range): } 31-46 \mathrm{~g}\end{array}$ & $5 \%$ aqueous extract & 28 days & $\pi$ & $\pi$ & $\pi$ & - \\
\hline \multirow{4}{*}{$\begin{array}{l}\text { Cardamom } \\
\text { Elettaria } \\
\text { cardamomum }\end{array}$} & Gilani et al. & $\mathrm{R} / \mathrm{CT}$ & 5 Sprague-Dawley rats & Crude extract & 6 hours & & & & \\
\hline & 2007 & & Weight (range): $200-220 \mathrm{~g}$ & $1 \mathrm{mg} / \mathrm{kg}$ & & $\pi$ & $\pi$ & $\pi$ & - \\
\hline & & & Swiss albino mice & $3 \mathrm{mg} / \mathrm{kg}$ & & $\pi$ & $\pi$ & $\pi$ & - \\
\hline & & & Weight (range): 20-25 g & $10 \mathrm{mg} / \mathrm{kg}$ & & $\pi$ & $\pi$ & $\pi$ & - \\
\hline $\begin{array}{l}\text { Aniseed oil } \\
\text { Pimpinella anisum }\end{array}$ & $\begin{array}{l}\text { Kreydiyyeh et } \\
\text { al. } 2003\end{array}$ & $\mathrm{CT}$ & $\begin{array}{l}5 \text { male Sprague-Dawley rats } \\
\text { Weight (range): 150-200 g }\end{array}$ & $0.5 \mathrm{ml} \mathrm{oil} / \mathrm{L}$ & 24 hours & K & - & - & - \\
\hline Java tea & Adam at al. & CT & 4 male Sprague-Dawley rats & Aqueous extract: & 4 hours & & & & \\
\hline Orthosiphon & 2009 & & Weight (range):180-200 g & $5 \mathrm{mg} / \mathrm{kg}$ & & $\pi$ & 0 & $\pi$ & 0 \\
\hline stamineus & & & & $10 \mathrm{mg} / \mathrm{kg}$ & & $\pi$ & 0 & $\pi$ & 0 \\
\hline
\end{tabular}

This article is protected by copyright. All rights reserved 


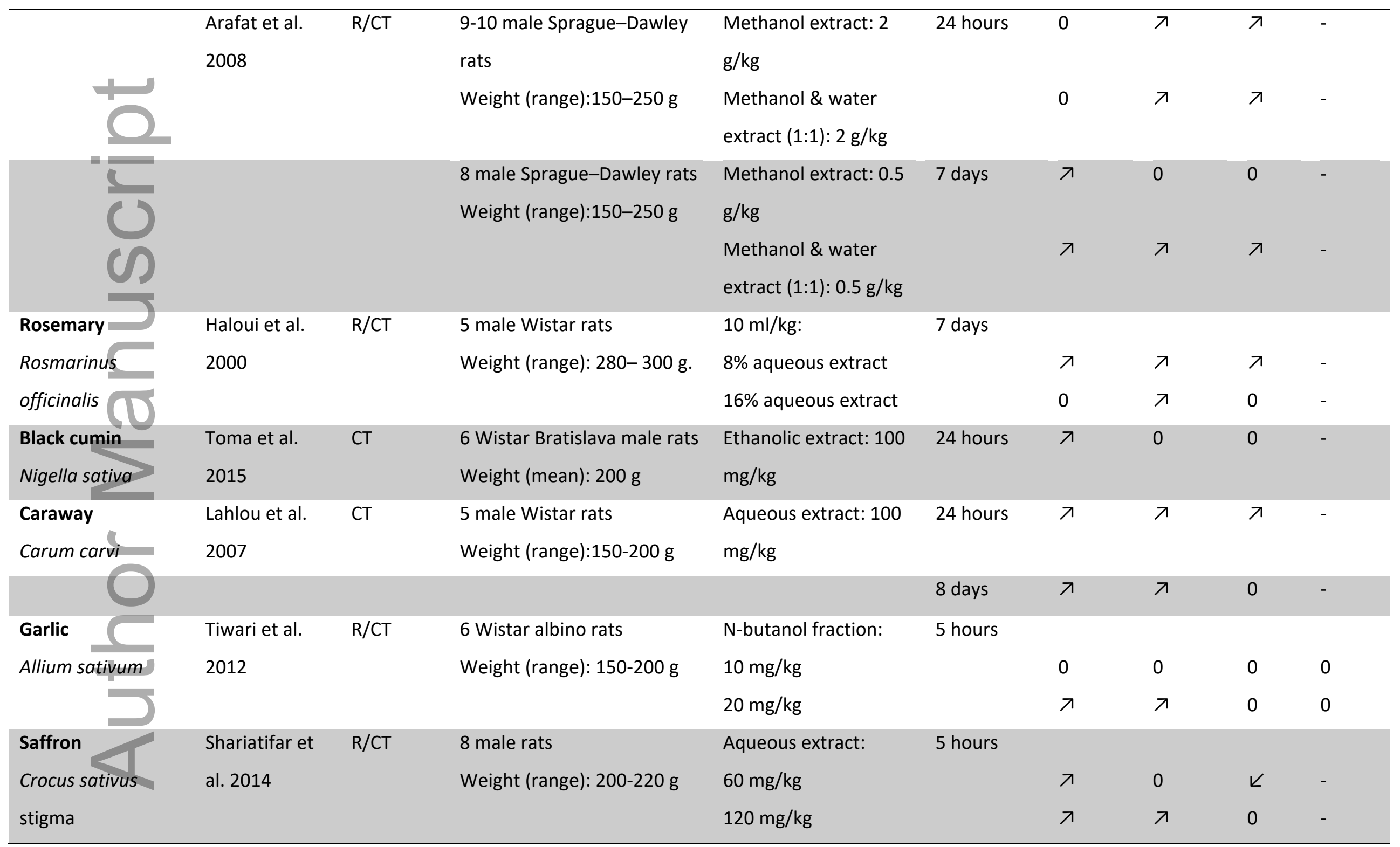

This article is protected by copyright. All rights reserved 


\section{VEGETABLES}

\begin{tabular}{|c|c|c|c|c|c|c|c|c|c|}
\hline \multicolumn{10}{|l|}{ ANIMAL STUDIES } \\
\hline Moringa & Fekadu et al. & $\mathrm{R} / \mathrm{CT}$ & 5 male Wistar rats & Aqueous extract: & 5 hours & & & & \\
\hline \multirow[t]{9}{*}{ Moringa } & 2017 & & Age (range): 4-6 weeks & $62.5 \mathrm{mg} / \mathrm{kg}$ & & $\pi$ & $\pi$ & 0 & 0 \\
\hline & & & Weight (range): 200-250 g & $125 \mathrm{mg} / \mathrm{kg}$ & & ス & $\pi$ & 0 & ス \\
\hline & & & & $250 \mathrm{mg} / \mathrm{kg}$ & & $\nearrow$ & $\nearrow$ & 0 & $\lambda$ \\
\hline & & & & $500 \mathrm{mg} / \mathrm{kg}$ & & ス & $\nearrow$ & $\nearrow$ & ス \\
\hline & & & & Hot tea infusion: & & & & & \\
\hline & & & & 1 teaspoons & & $\pi$ & ス & 0 & 0 \\
\hline & & & & 2 , teaspoons & & $\nearrow$ & $\nearrow$ & 0 & 0 \\
\hline & & & & 4 teaspoons & & $\nearrow$ & $\nearrow$ & $\pi$ & $\lambda$ \\
\hline & & & & 6 teaspoons & & 0 & ス & $\nearrow$ & オ \\
\hline \multirow{4}{*}{$\begin{array}{l}\text { Nasturtium } \\
\text { Tropaeolum majus }\end{array}$} & Gasparotto & $\mathrm{CT}$ & 5 spontaneously & Ethanolic extract: & 7 days & & & & \\
\hline & Junior et al. & & hypertensive male rats & $300 \mathrm{mg} / \mathrm{kg}$ & & $\nearrow$ & ス & 0 & 0 \\
\hline & 2012 & & Age (range): 3-4 months & & & & & & \\
\hline & & & Weight (range): $250-300 \mathrm{~g}$ & & & & & & \\
\hline \multirow{4}{*}{$\begin{array}{l}\text { Amaranth } \\
\text { Amaranthus } \\
\text { spinosus }\end{array}$} & Amuthan et al. & $\mathrm{CT}$ & 6 male albino Wistar rats & Aqueous extract: & 24 hours & & & & \\
\hline & 2012 & & Weight (range):150-200 g & $200 \mathrm{mg} / \mathrm{kg}$ & & 0 & 0 & 0 & 0 \\
\hline & & & & $500 \mathrm{mg} / \mathrm{kg}$ & & 0 & ス & $\pi$ & ス \\
\hline & & & & 1000 mg/kg & & 0 & 0 & 0 & 0 \\
\hline
\end{tabular}

This article is protected by copyright. All rights reserved 


\begin{tabular}{|c|c|c|c|c|c|c|c|c|c|}
\hline & & & & $1500 \mathrm{mg} / \mathrm{kg}$ & & 0 & 0 & $\pi$ & $\pi$ \\
\hline \multirow{8}{*}{$\begin{array}{l}\text { Wild mushroom } \\
\text { Polyporus } \\
\text { umbellatus }\end{array}$} & Zhang et al. & CT & 6 male Sprague-Dawley rats & Aqueous extract: & 24 hours & & & & \\
\hline & 2010 & & Weight (range):180-200 g & $50 \mathrm{mg} / \mathrm{kg}$ & & $\pi$ & $\pi$ & $\pi$ & $\pi$ \\
\hline & & & & $250 \mathrm{mg} / \mathrm{kg}$ & & $\lambda$ & $\lambda$ & $\lambda$ & $\pi$ \\
\hline & & & & $500 \mathrm{mg} / \mathrm{kg}$ & & $\lambda$ & $\lambda$ & $\pi$ & $\pi$ \\
\hline & & & & Aqueous extract: & 8 days & & & & \\
\hline & & & & $50 \mathrm{mg} / \mathrm{kg}$ & & 0 & $\pi$ & $\pi$ & $\pi$ \\
\hline & & & & $250 \mathrm{mg} / \mathrm{kg}$ & & $\lambda$ & $\pi$ & $\lambda$ & $\pi$ \\
\hline & & & & $500 \mathrm{mg} / \mathrm{kg}$ & & $\lambda$ & $\pi$ & $\pi$ & $\pi$ \\
\hline \multirow{6}{*}{$\begin{array}{l}\text { Roselle } \\
\text { Hibiscus sabdariffa }\end{array}$} & Alarcón- & CT & 6 male Albino Sprague- & Aqueous extract: & 5 hours & & & & \\
\hline & Alonso et al. & & Dawley Rats & $500 \mathrm{mg} / \mathrm{kg}$ & & 0 & $\pi$ & 0 & 0 \\
\hline & 2012 & & Weight (range):250-280 g & $1000 \mathrm{mg} / \mathrm{kg}$ & & 0 & $\pi$ & 0 & $\pi$ \\
\hline & & & & $1500 \mathrm{mg} / \mathrm{kg}$ & & $\pi$ & $\lambda$ & 0 & $\pi$ \\
\hline & & & & $2000 \mathrm{mg} / \mathrm{kg}$ & & $\lambda$ & $\lambda$ & 0 & $\pi$ \\
\hline & & & & $2500 \mathrm{mg} / \mathrm{kg}$ & & $\pi$ & $\pi$ & 0 & $\pi$ \\
\hline Black radish & Vargas S. et al. & CT & Male albino rats & Aqueous extract: & 24 hours & & & & \\
\hline Raphanus sativus & 1999 & & Weight (range): $200-250 \mathrm{~g}$ & $40 \mathrm{mg} / \mathrm{kg}$ & & $\lambda$ & - & - & - \\
\hline & & & & $70 \mathrm{mg} / \mathrm{kg}$ & & $\pi$ & - & - & - \\
\hline & & & & $140 \mathrm{mg} / \mathrm{kg}$ & & $\pi$ & - & - & - \\
\hline Sorrel & Rao et al. 2011 & CT & 4 male albino rats & Ethanol extract: & 6 hours & & & & \\
\hline Rumex vesicariys & & & Weight (range): $150-200 \mathrm{~g}$ & $750 \mathrm{mg} / \mathrm{kg}$ & & $\pi$ & 0 & $\pi$ & 0 \\
\hline & & & & $1000 \mathrm{mg} / \mathrm{kg}$ & & $\pi$ & $\pi$ & $\lambda$ & $\pi$ \\
\hline
\end{tabular}

This article is protected by copyright. All rights reserved 


\begin{tabular}{|c|c|c|c|c|c|c|c|c|c|}
\hline & & & & \multicolumn{6}{|l|}{ Benzene extract } \\
\hline & & & & \multirow{2}{*}{\multicolumn{2}{|c|}{$\begin{array}{l}750 \mathrm{mg} / \mathrm{kg} \\
1000 \mathrm{mg} / \mathrm{kg}\end{array}$}} & \multirow{2}{*}{$\begin{array}{l}0 \\
0\end{array}$} & \multirow{2}{*}{$\begin{array}{l}K \\
0\end{array}$} & \multirow{2}{*}{$\begin{array}{l}0 \\
0\end{array}$} & \multirow{2}{*}{$\begin{array}{l}\lambda \\
\pi\end{array}$} \\
\hline & & & & & & & & & \\
\hline Kidney leaf & Angappan et & CT & 5 female Wistar albino rats & Aqueous extract: & 5 hours & & & & \\
\hline morning glory & al. 2018 & & Weight (range): 150-200 g & $200 \mathrm{mg} / \mathrm{kg}$ & & 0 & 0 & 0 & - \\
\hline Merremia & & & & $400 \mathrm{mg} / \mathrm{kg}$ & & 0 & 0 & 0 & - \\
\hline emargina & & & & $600 \mathrm{mg} / \mathrm{kg}$ & & $\pi$ & $\lambda$ & $\lambda$ & - \\
\hline \multicolumn{10}{|l|}{ FRUITS } \\
\hline \multicolumn{10}{|l|}{ ANIMAL STUDIES } \\
\hline Prickly pear & Galati et al. & CT & 12 male Wistar rats & $5 \mathrm{ml} / 100 \mathrm{~g}$ of: & 24 hours & & & & \\
\hline \multirow{3}{*}{ Opuntia ficus indica } & 2002 & & Weight (range): $150-200 \mathrm{~g}$ & $15 \%$ cladodes infusion & & $\pi$ & 0 & 0 & - \\
\hline & & & & $15 \%$ flowers infusion & & $\pi$ & 0 & 0 & - \\
\hline & & & & $15 \%$ fruits infusion & & $\pi$ & 0 & 0 & - \\
\hline & & & & $1.5 \mathrm{ml} / 100 \mathrm{~g}$ of: & 7 days & & & & \\
\hline & & & & $15 \%$ cladodes infusion & & $\pi$ & - & - & - \\
\hline & & & & $15 \%$ flowers infusion & & $\lambda$ & - & - & - \\
\hline & & & & $15 \%$ fruits infusion & & $\pi$ & - & - & - \\
\hline \multirow{5}{*}{$\begin{array}{l}\text { Grangel } \\
\text { Randia echinocarpa }\end{array}$} & Vargas Solis et & CT & Male albino rats & Aqueous extract: & 24 hours & & 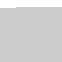 & 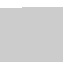 & \\
\hline & al. 2002 & & Weight (range): $200-250 \mathrm{~g}$ & $10 \mathrm{mg} / \mathrm{kg}$ & & 0 & - & - & - \\
\hline & & & & $20 \mathrm{mg} / \mathrm{kg}$ & & $\pi$ & - & - & - \\
\hline & & & & $40 \mathrm{mg} / \mathrm{kg}$ & & $\pi$ & - & - & - \\
\hline & & & & $60 \mathrm{mg} / \mathrm{kg}$ & & $\pi$ & - & - & - \\
\hline
\end{tabular}

This article is protected by copyright. All rights reserved 


\begin{tabular}{|c|c|c|c|c|c|c|c|c|c|}
\hline Wild raspberry & Zhang et al. & $\mathrm{CT}$ & 6 male rats & $2 \mathrm{~g} / \mathrm{kg}$ : & 4 hours & & & & \\
\hline \multirow{2}{*}{ Rubus idaeus } & 2011 & & Weight (range): 250-300 g & Aqueous extract & & 0 & 0 & $K$ & - \\
\hline & & & & Methanol extract & & $\nearrow$ & $\nearrow$ & K & - \\
\hline \multirow{3}{*}{$\begin{array}{l}\text { Goji berries } \\
\text { Lycium barbarum }\end{array}$} & Pai et al. 2014 & $\mathrm{CT}$ & 6 Wistar albino rats & Fruit powder: & 24 hours & & & & \\
\hline & & & Weight (range): 150-200 g & $250 \mathrm{mg} / \mathrm{kg} / \mathrm{day}$ & & ス & ス & $K$ & ス \\
\hline & & & & $500 \mathrm{mg} / \mathrm{kg} / \mathrm{day}$ & & $\nearrow$ & $\nearrow$ & $K$ & $\pi$ \\
\hline \multirow{3}{*}{$\begin{array}{l}\text { Bijaura fruit } \\
\text { Citrus medica }\end{array}$} & Shah et al. & $\mathrm{R} / \mathrm{CT}$ & 6 urolithiasis induced male & Fresh fruit juice: & 28 days & $\nearrow$ & - & - & - \\
\hline & 2014 & & Wistar rats & $250 \mathrm{mg} / \mathrm{kg}$ & & & & & \\
\hline & & & Weight (range): 250-300 g & & & & & & \\
\hline
\end{tabular}

CO: crossover, R: randomized, CT: control/placebo, UV: urinary volume, $\mathrm{UNa}^{+}$: urinary sodium, UK ${ }^{+}$: urinary potassium, UCl': urinary chloride, - : not

reported, 0: no significant effect, $\lambda$ : significant increase, $\measuredangle$ : significant decrease. The number of animals is mentioned per test group. Test dosages of herbal/spice extracts were mentioned based on their extraction methods as either "aqueous" or "methanol"/"ethanol". The latter involved extraction of dry ground materials using alcohol-based solvent which was then vacuum evaporated.

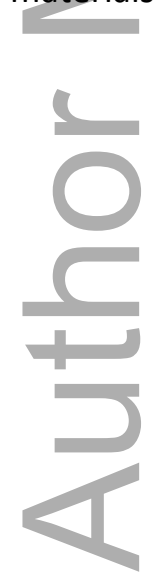

This article is protected by copyright. All rights reserved 


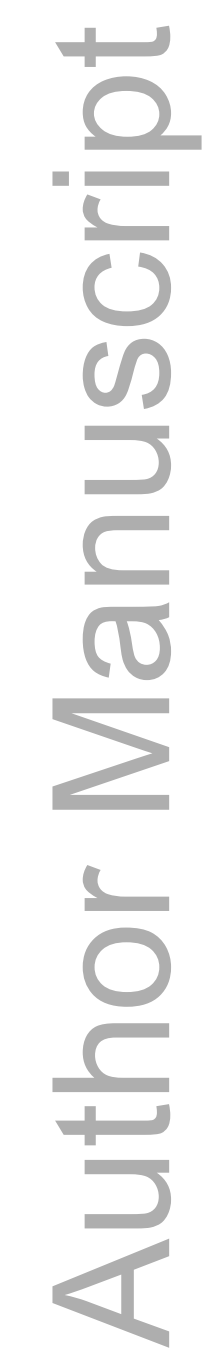

This article is protected by copyright. All rights reserved 


\section{Figure 1: Study Selection Flow Diagram}

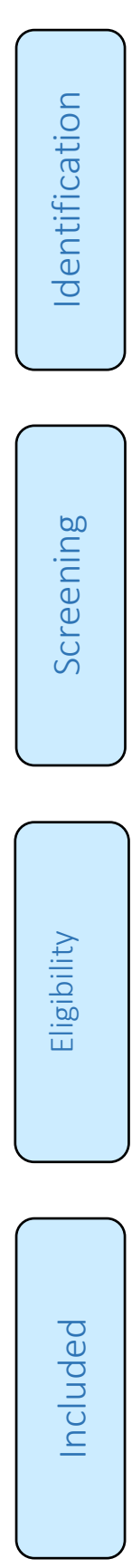

Records identified through database MEDLINE ( $n=703)$

EMBASE $(n=1328)$
Records identified through other sources

$(n=84)$

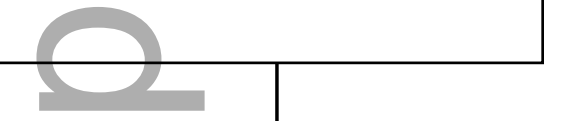

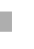

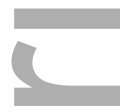

()
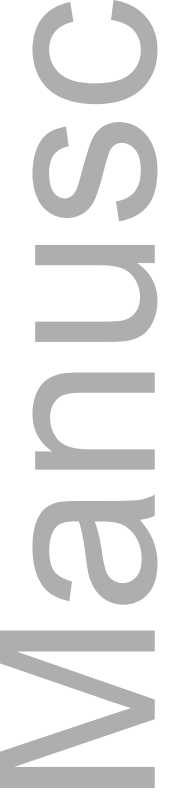

Full-text articles assessed for eligibility

$(n=256)$

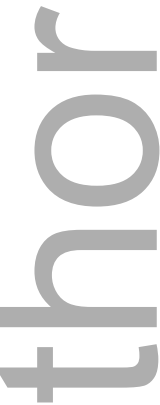

Records after duplicates removed

$(n=2110)$
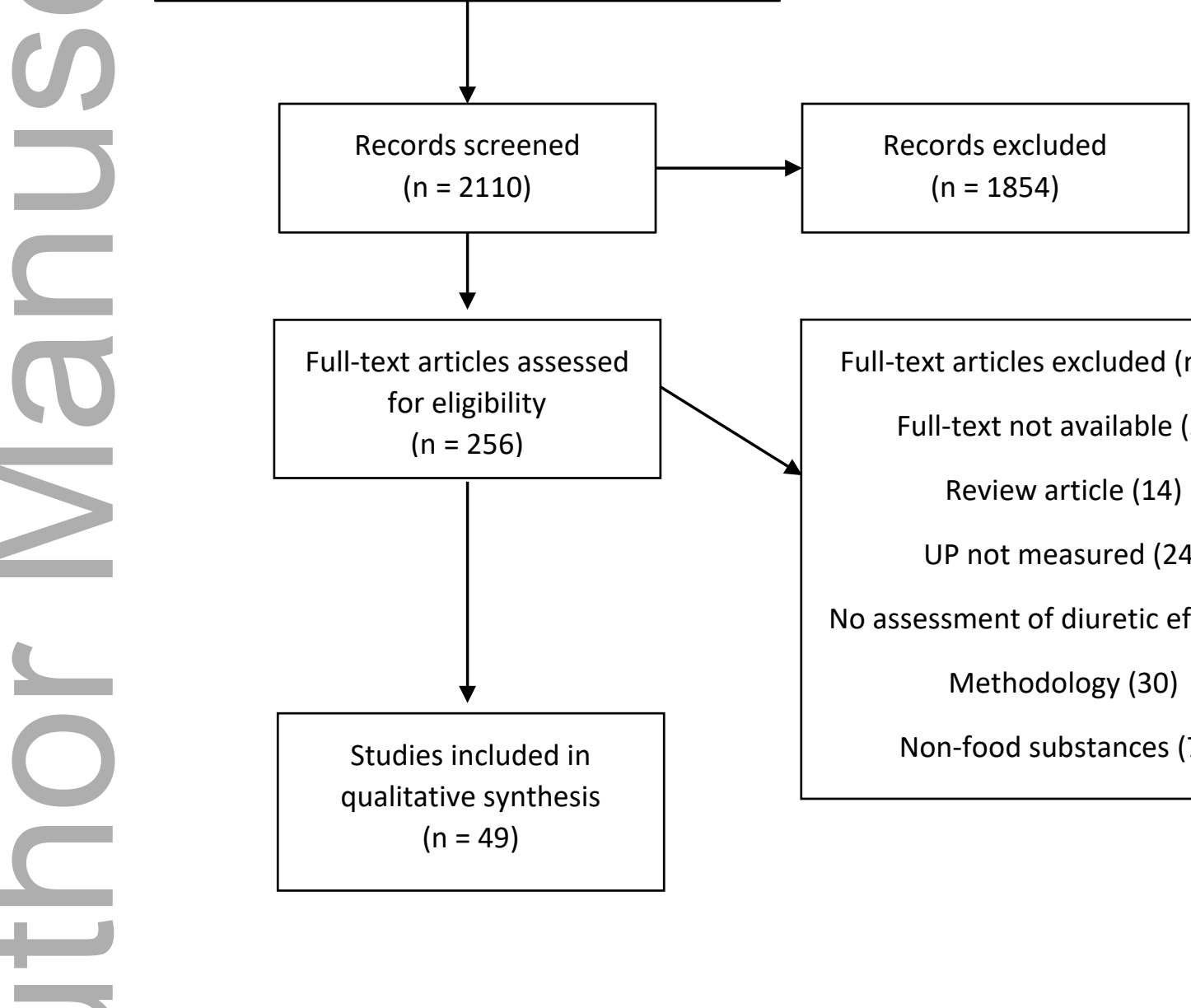

Studies included in qualitative synthesis

$$
(n=49)
$$

Note: Abbreviations: UP - Urine Production 
Figure 2: Proposed experimental plan for the development of a Food Diuretic Index

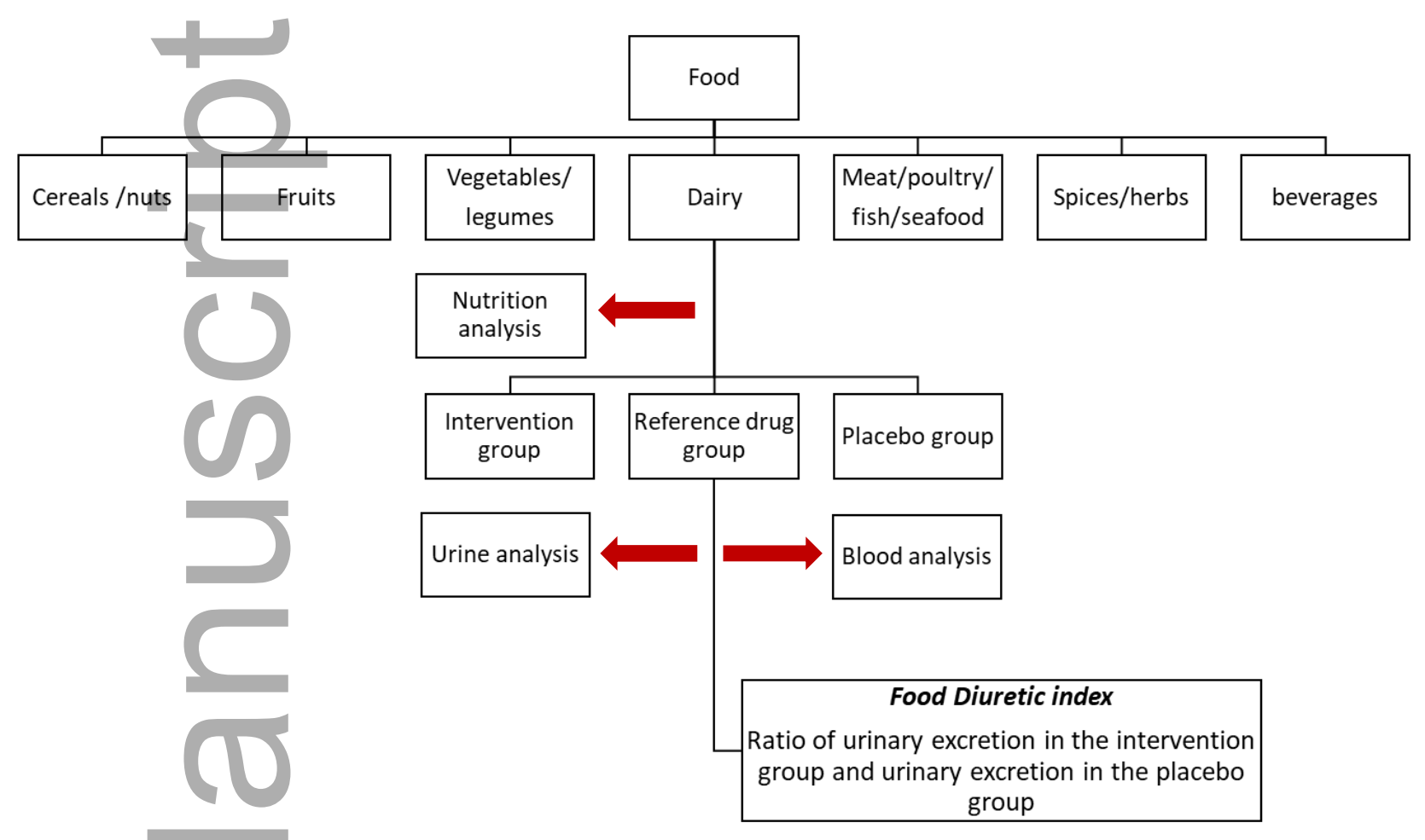

This article is protected by copyright. All rights reserved 


\section{University Library}

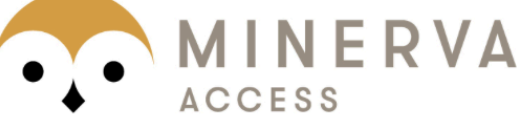

A gateway to Melbourne's research publications

Minerva Access is the Institutional Repository of The University of Melbourne

Author/s:

Alwis, US;Haddad, R;Monaghan, TF;Abrams, P;Dmochowski, R;Bower, W;Wein, AJ;Roggeman, S;Weiss, JP;Mourad, S;Delanghe, J;Everaert, K

Title:

Impact of food and drinks on urine production: A systematic review

Date:

2020-06-09

\section{Citation:}

Alwis, U. S., Haddad, R., Monaghan, T. F., Abrams, P., Dmochowski, R., Bower, W., Wein, A. J., Roggeman, S., Weiss, J. P., Mourad, S., Delanghe, J. \& Everaert, K. (2020). Impact of food and drinks on urine production: A systematic review. INTERNATIONAL JOURNAL OF CLINICAL PRACTICE, 74 (9), https://doi.org/10.1111/ijcp.13539.

Persistent Link:

http://hdl.handle.net/11343/275882 